\title{
Models of Gastroenteropancreatic Neuroendocrine Neoplasms: Current Status and Future Directions
}

\author{
Katharina Detjen Linda Hammerich Burcin Özdirik Münevver Demir \\ Bertram Wiedenmann Frank Tacke Henning Jann Christoph Roderburg \\ Department of Hepatology and Gastroenterology, Charité - University Medicine Berlin, Campus Virchow Klinikum \\ and Charité Campus Mitte, Berlin, Germany
}

\author{
Keywords \\ Gastroenteropancreatic neuroendocrine tumor · \\ Neuroendocrine carcinoma - Therapy · Mouse model • \\ Patient-derived xenograft
}

\begin{abstract}
Gastroenteropancreatic neuroendocrine neoplasms (GEPNENs) are a rare, heterogeneous group of tumors that originate from the endocrine system of the gastrointestinal tract and pancreas. GEP-NENs are subdivided according to their differentiation into well-differentiated neuroendocrine tumors (NETs) and poorly differentiated neuroendocrine carcinomas (NECs). Since GEP-NENs represent rare diseases, only limited data from large prospective, randomized clinical trials are available, and recommendations for treatment of GEP-NEN are in part based on data from retrospective analyses or case series. In this context, tractable disease models that reflect the situation in humans and that allow to recapitulate the different clinical aspects and disease stages of GEP-NET or GEP-NEC are urgently needed.

In this review, we highlight available data on mouse models for GEP-NEN. We discuss how these models reflect tumor biology of human disease and whether these models could serve as a tool for understanding the pathogenesis of GEP-
\end{abstract}

\begin{tabular}{ll}
\hline karger@karger.com & (c) 2020 The Author(s) \\
Pww.karger.com/nen & $\begin{array}{l}\text { Published by S. Karger AG, Basel } \\
\text { This is an Open Access article licensed under the Creative Commons }\end{array}$ \\
Karger & $\begin{array}{l}\text { Attribution-NonCommercial-4.0 International License (CC BY-NC) } \\
\text { (http://www.karger.com/Services/OpenAccessLicense), applicable to } \\
\text { the online version of the article only. Usage and distribution for com- } \\
\text { mercial purposes requires written permission. }\end{array}$
\end{tabular}

NEN and for disease modeling and pharmacosensitivity assays, facilitating prediction of treatment response in patients. In addition, open issues applicable for future developments will be discussed.

(c) 2020 The Author(s)

Published by S. Karger AG, Basel

\section{Introduction}

Gastroenteropancreatic neuroendocrine neoplasms (GEP-NENs) represent a heterogeneous group of rare tumors that originate from the diffuse endocrine system of the gastrointestinal tract and pancreas. They are characterized by the expression of neuroendocrine markers including synaptophysin and chromogranin A. The incidence of neuroendocrine neoplasms (NENs) has significantly risen in the last 30 years, due to improved diagnostic techniques as well as awareness. The current age-adjusted incidence of GEP-NEN is estimated to be 6.98 cases per 100,000 persons for gastroenteropancreatic neuroendocrine tumors (GEP-NET) [1] and 0.4 cas-

K.D. and L.H. share first authorship. H.J. and C.R. share senior authorship. 
es per 100,000 persons for gastroenteropancreatic neuroendocrine carcinoma (GEP-NEC) [2] in the USA.

GEP-NENs demonstrate a variable clinical behavior depending on the primary location and the differentiation of the tumor. They are classified based on the Ki67 proliferative index: well-differentiated NET G1 displays a Ki67 index of $<3 \%$ and NET G2 display a Ki67 index of 3-20\%. G3 NENs with Ki67 fractions $>20 \%$ are subclassified according to their morphological differentiation into GEP-NET G3 and undifferentiated GEP-NEC $[3,4]$. Patients with well-differentiated NET G1 or G2 have an extraordinarily good prognosis [1], whereas survival in the G3 group ranges from several years in well-differentiated NET G3 to few month in poorly differentiated NEC with $\mathrm{Ki} 67 \geq 55 \%[3,4]$.

\section{Molecular Features of GEP-NET and GEP-NEC}

Earlier information about the molecular underpinnings of NEN was mostly derived from observations in genetic syndromes. Hereditary GEP-NET syndromes include multiple endocrine neoplasia type 1 (MEN1) and type 4 (CDKN1B), tuberous sclerosis complex (TSC), von Hippel-Lindau (VHL), and neurofibromatosis type 1, which have been reviewed in detail elsewhere $[5,6]$. Most importantly, MEN1 is an autosomal dominant syndrome, associated with pancreatic NETs (pNETs), which are caused by an inactivating mutation in MEN1, encoding for menin. Although its function is not yet fully clear, menin has been shown to act as a nuclear scaffold for transcription factors and chromatin modifying enzymes, thereby regulating pathways involved in growth and differentiation such as histone methylation, DNA damage repair, activity of the mTOR pathway, and inhibition of cell cycle progression [7].

Recently, several previously unknown hereditary NET syndromes have been identified, characterized by loss-offunction mutations in IPMK [8], MUTYH, and OGG1 [9], all affecting p53 function and/or DNA repair pathways. Furthermore, loss-of-function mutations in a subunit of the parietal cell proton pump (ATP4A) cause familial gastric NET [10].

Several of the genes that cause familial NEN syndromes are by now equally attributed to sporadic pancreatic NEN (pNEN) and small intestinal NEN (siNEN). MEN1 represents the most frequently affected gene in pNEN, followed by mutually exclusive mutations in death domain-associated protein (DAXX) or ATR-X (ATRX) $[11,12]$. The latter 2 cooperate in deposition of histone
H3.3 at telomeres, and mutations were found associated with alternative lengthening of telomeres [13] and chromosomal instability [14]. Either single or combined mutation of MEN1, DAXX, or ATRX in pNET is associated with features of islet $\alpha$-cells and an adverse prognostic course [15]. Mutations within the cyclin-dependent kinase inhibitor CDKN1B, in DEPDC5 (suppressor of the mTOR-AKT pathway), PTEN, TSC1, and TSC2, were also recurrently present in NET [12, 16-18], implicating the mTOR network. Overall, however, the frequency of somatic mutations in NEN is low and epigenetic changes are increasingly recognized as drivers in $\operatorname{NEN}[5,19,20]$. In pNET, such epigenetic features allow separation of 2 prognostic subgroups with distinct developmental features of $\alpha$ - or $\beta$-cell identity [21].

A distinctly different mutation profile characterizes GEP-NECs, which harbor mutations in the tumor suppressors tumor protein P53 (TP53) and retinoblastoma transcriptional corepressor 1 (RB1) in up to $70 \%$ of cases (reviewed in [5]). The almost universal inactivation of TP53 and RB1 is a well-documented feature of SCLC, which is perceived as closely related to GEP-NEC. The high rates of TP53 and RB mutations in NECs may help in differentiating NETs from NECs [22]. NECs furthermore share genetic features of adenocarcinomas from corresponding sites, for example, mutation of APC, BRAF, and K-RAS, and microsatellite instability [23, 24].

\section{Models of GEP-NET and GEP-NEC}

Advanced and faithful model systems have become a key to new insights into the molecular pathogenesis of rare tumor diseases. Indeed, progress in the generation of genetically modified organisms and the establishment of patient-derived xenograft $(\mathrm{pdx})$ models improved our understanding of GEP-NEN. However, it also became clear that these experimental systems mostly reflect pNEN, do not fully recapitulate the mutation landscape, and only partially reflect the pathophysiology of human NENs. Here, we summarize current preclinical in vivo and in vitro models for GEP-NENs and discuss their advantages and limitations. We deliberately confined the in vivo part to mouse models and refer readers to earlier reviews for additional coverage of GEP-NEN in other model organisms such as rat or zebra fish [25].

\section{Cell Lines and Cell Line-Derived Xenografts}

The lack of large and representative panels of human NEN cell lines has long been a major obstacle in transla- 
Table 1. Overview of human GEP-NET models, indicating the site of origin of the parental human tumor and the source of the tissue used for initial implantation or culture

\begin{tabular}{|c|c|c|c|c|c|c|}
\hline Designation & $\mathrm{pdx}$ & In vitro culture & Xenograft & Origin & Primary/metastasis & Reference \\
\hline QGP-1 ${ }^{\mathrm{a}}$ & & Cell line & + & Pancreas & Primary & Kaku et al. [27] \\
\hline $\mathrm{CM}$ & & Cell line & & Pancreas (insulinoma) & Metastasis (ascites) & Gueli et al. [29] \\
\hline GOT1 & & Cell line & + & Small intestine & Metastasis (liver) & Kölby et al. [28] \\
\hline HuNET & & Cell line & Failed & Pancreas & Primary & Tillotson et al. [31] \\
\hline P-STS & & Cell line & + & Small intestine & Primary & Pfragner et al. [30] \\
\hline HNV PDX-PNET & + & & & Pancreas (insulinoma) & Metastasis (liver) & Chamberlain et al. [46] \\
\hline PONETCL & & Cell line & & Rectum & Metastasis (liver) & Alvarez et al. [37] \\
\hline
\end{tabular}

Models are organized chronologically. Reports of primary cultures are notincluded.GEP-NET, gastroenteropancreaticneuroendocrine

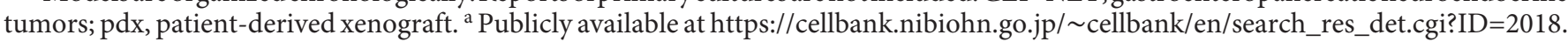

tional NEN research. The commonly used cell lines that originate from well-differentiated NET, that is, BON-1 [26], QGP-1 [27], and GOT-1 [28] were established decades ago and have proven to be valuable and easy to manipulate tools despite their much-discussed shortcomings (see Table 1 for available human NET cell lines). They are tumorigenic when implanted in nude mice and have been variably used in settings of subcutaneous, orthotopic, or metastatic tumor growth. In the latter application, xenografts have been helpful for studies of metastatic growth, which is poorly represented in most genetically modified mouse models of GEP-NET. CM insulinoma cells exhibit functional insulin secretion [29] but have not been reported to grow as xenografts. P-STS was first described in 2009 [30] and was later used as in vitro model for studying secretion in siNET. Several other cell lines have become available over time, but difficulties in maintaining the lines or their neuroendocrine identity have prevented broader use [30-32]. Excellent reviews on the origin and properties of GEP-NEN cell lines have been published $[32,33]$.

A recent promising addition to the repertoire of NET cell lines are NT-3 cells, which were established from a lymph node metastasis of a functional insulinoma obtained from a 33-year-old patient [34]. NT-3 cells form slow growing subcutaneous xenograft tumors, maintain the well-differentiated phenotype and functionality of the original tumor, and exhibit a Ki67 fraction of 15-25\% akin to the human tissue. Another pNEN cell line as well as a siNET organoid line were recently announced by the NET research foundation and will be made available to all NEN researchers through the American Type Culture
Collection (https://netrf.org/2020/03/11/net-cell-line/). Together with NT-3 and APL1 cells described in the "pdx, Organoid Cultures and Primary Cultures" section, such new lines will offer valuable alternatives to existing BON and QGP1 models. The latter 2 have been fully sequenced, which revealed mutational profiles similar to pNEC rather than pNET, for example, TP53 and RAS mutations. Indeed, results from next-generation sequencing and transcriptome analyses have illustrated considerable differences between permanent NET cell lines and patients' tumor tissues [35, 36], but also advocated cell lines as suitable tools, if they are validated in respect to clinical NEN samples [37]. Despite all shortcomings, established cell lines will remain valuable because they offer an unlimited and easy to manipulate source of material in a rare disease. In addition, established cell lines might be improved by genetic engineering based on our increasing knowledge of the genetic landscapes of NEN.

\section{pdx, Organoid Cultures, and Primary Cultures}

Recently, pdx took center stage as models for preclinical drug evaluation, biologic studies, biomarker identification, and personalized medicine strategies [38, 39]. pdx models stem from direct implantation of human tumor tissue into immunodeficient animals [40], retain histologic and genetic characteristics of their donor tumor, and exhibited drug response rates that predict clinical response in first prospective trials. Pdx models may be passaged repeatedly and thus used over long time periods, although shifts in the genetic landscape may occur [41]. The major disadvantage that $\mathrm{pdx}$ models share with conventional xenografts is the need for immunodeficient 
mice, which prevents any studies of tumor-immune interactions or immunotherapies.

As results from larger series of systematic engraftment of NEN tissues are emerging, they emphasize the difficulty to obtain pdx from well-differentiated NEN. This is in line with the low number of permanent human NET cell lines that are available $[32,33]$, and with the comparatively late first reports of expandable organoid cultures of NET $[42,43]$. Altogether, this attests to the need for an improved understanding of the microenvironment required for the propagation of these tumors (see Table 1 for overview of human GEP-NET models).

In the largest series of $\mathrm{pdx}$ reported to date, 1 model was obtained from 106 engrafted GI NEN and CUPs [44]. Initial tumor formation was achieved in 7 cases, but 6 of these tumors failed subsequent reengraftment. The $1 \mathrm{re}-$ maining pdx originated from a metastatic tumor with a Ki67 fraction of 70-90\% as well as a novel, possibly truncating TP53 mutation, both features suggestive of a biology more representative of an NEC.

A second study focused specifically on well-differentiated pancreatic NET [45]. One pdx model plus a corresponding cell line resulted from 39 engrafted samples. The tissue originated from a liver metastasis of a nonfunctioning G1 pNET. Both, pdx and APL1 cells derived from the pdx exhibit autocrine HGF-MET signaling, suggesting them as a useful pNET model for drugs targeted at this pathway. The authors furthermore identified CD47 as a feature of a pNEN tumor stem cell population in this model.

Another pdx model of pNEN was derived from liver metastases of a malignant insulinoma [46]. Both, pdx and original tumor sustained mutations of MEN1, BRCA2, SETD2, and PTEN, rendering this pdx uniquely suitable for evaluation of mTOR pathway inhibitors. Indeed, everolimus and sapanisertib suppressed growth in this pdx model. Of interest sapanisertib reduced growth of pdx tumors, which had become resistant to everolimus, suggesting that 2 nd generation mTor inhibitors might benefit patients who acquired everolimus resistance.

In contrast to the discouraging success rates of $\mathrm{pdx}$ from well-differentiated NET, a number of independent reports on pdx, cell lines, and xenografts derived from NEC suggest better feasibility [47-64]. As GEP-NECs are rare and access to NEC tissues even more limited, there are no data from systematic engraftment series available. Thus, the number of pdx models is still small, but a steady increase of available NEC cell lines that can be grown as xenografts suggests that NEC models are more easily generated. To our knowledge, at least 19 NECs have been established as pdx, cell line, or organoid culture, and several of them have been characterized with respect to cisplatin sensitivity in vitro, or in xenografts in vivo (overview in Table 2). Although the level of characterization widely varies across lines, mutations in TP53, RB, K-RAS, and B-RAF were reported, suggesting a fair representation of the alterations observed in clinical NEC specimens $[23,65,66]$.

Several groups have managed to establish small panels of NEC models in vitro $[53,56,59,62,63,67-70]$. The parallel establishment of a pdx and a corresponding cell line, HROC57, from a poorly differentiated large cell colorectal NEC carrying a B-Raf mutation is such an example [64]. The cell line exhibited susceptibility to etoposide, cisplatin, and 5-FU, but not rapamycin, a drug response profile consistent with clinical observations in NEC. Similarly, 2 NEC samples were grown as part of a large colorectal organoid library [59]. They formed a distinct subgroup at the transcriptome level, and both carried p53 mutations. In addition, mutations in APC, BRAF, and K-RAS were present in 1 organoid. Niche factor dependence for culturing reflected the difference in mutation profiles. Of note, the NEC culture without APC mutation depended on wnt/R-spondin supplements for growth in culture.

Jiang et al. [57] developed the HuPrime ${ }^{\circledR}$ human gastric NEC-derived pdx model GA0087 with interesting features for drug testing: even when maintained as subcutaneous tumor, GA0087 released circulating tumor cells and showed high potential of lung metastasis, possibly due to high expression of vascular endothelial growth factors-A and B. Both primary tumor growth and metastasis were effectively suppressed by cisplatin [57].

NEC xenografts and cell lines are mostly of GI origin, likely reflecting a better availability of surgical material from these sites. A remarkable exception are A99 cells, which stem from a small cell pancreatic NEC and were established as permanent culture after 1 initial passage as pdx [55]. Engraftment of A99 cells into nude mice efficiently produced xenograft tumors with the characteristic small cell morphology of the original human donor tumor. The cells exhibit homozygous mutations in KRAS and TP53 as well as numerical and structural chromosomal alterations with similarity to SCLC. At the protein level, A99 cells were positive for multiple NE markers but not for $\mathrm{pRb}$ and $\mathrm{pdx} 1$.

Despite the difficulties encountered when growing NETs as pdx or permanent cell lines, NET cells can be maintained as primary cultures for several days and be subjected to pharmacologic testing $[32,71-74]$. In gen- 
Table 2. Overview of human GEP-NEC models, indicating the site of origin of the parental human tumor and the source of the tissue used for initial implantation or culture

\begin{tabular}{|c|c|c|c|c|c|c|c|c|}
\hline \multirow{2}{*}{$\begin{array}{l}\text { Designation } \\
\text { COLO } 320\end{array}$} & \multirow[t]{2}{*}{$\mathrm{pdx}$} & \multirow{2}{*}{$\begin{array}{l}\begin{array}{l}\text { In vitro } \\
\text { culture }\end{array} \\
\text { Cell line }\end{array}$} & \multicolumn{2}{|c|}{ Xenograft origin } & \multirow{2}{*}{$\begin{array}{l}\text { Primary/metastasis } \\
\text { Primary }\end{array}$} & \multirow{2}{*}{$\begin{array}{l}\text { Reported mutations } \\
\text { TP53 (COLO } 320 \\
\text { DM) }\end{array}$} & \multirow{2}{*}{$\begin{array}{l}\text { Cisplatin } \\
\text { response }\end{array}$} & \multirow{2}{*}{$\begin{array}{l}\text { Reference } \\
\text { Quinn et al. [47] }\end{array}$} \\
\hline & & & + & Colon & & & & \\
\hline LCC-18 & & Cell line & + & Colon & Primary & & na & Lundqvist et al. [48] \\
\hline ECC18 & & Cell line & Failed & Esophagus (sc) & & & na & Fujiwara et al. [49] \\
\hline TEG13 & + & & & Esophagus (sc) & Primary & & $99 \%$ inhibition & Aizawa et al. [50] \\
\hline TSG15 & + & & & Stomach (sc) & Primary & & $69 \%$ inhibition & Aizawa et al. [50] \\
\hline $\begin{array}{l}\text { CT-nu-1 (cell line) } \\
\text { EN-1 (xenograft) }\end{array}$ & + & Cell line & + & Duodenum & Primary & & na & Konno et al. [51] \\
\hline N-TAK-1 & + & Cell line & & Rectum & Metastasis (lymph node) & & na & $\begin{array}{l}\text { Tanaka et al. [52], } \\
\text { Koizumi et al. [54] }\end{array}$ \\
\hline NECS-P/NECS-L & & Cell line & & Rectum & Primary + metastasis (liver) & & na & Takahashi et al. [53] \\
\hline A99 & + & Cell line & + & Pancreas (sc) & Metastasis (liver) & TP53; KRAS & $>10 \mu \mathrm{M}$ & Yachida et al. [55] \\
\hline NEC-DUE1 & & Cell line & + & Gastric (lc) & Metastasis (liver) & & $>10 \mu \mathrm{M}$ & Krieg et al. [56] \\
\hline NEC-DUE2 & & Cell line & + & Colon (lc) & Metastasis (lymph node) & & $>10 \mu \mathrm{M}$ & Krieg et al. [56] \\
\hline GA0087 & + & & & Stomach & Primary & & $64 \%$ inhibition & Jiang et al. [57] \\
\hline TYUC-1 & & Cell line & + & Esophagus (sc) & & & $0.87 \mu \mathrm{M}$ & Okumura et al. [58] \\
\hline CRC14 & & Organoid & + & Colon & Primary & $\begin{array}{l}\text { TP53; BRAF; KRAS; } \\
\text { APC; TCF7L2 }\end{array}$ & na & Fujii et al. [59] \\
\hline CRC19 & & Organoid & & Rectum & Primary & TP53 & na & Fujii et al. [59] \\
\hline ANI-27S & & Spheroid & & CUP & Metastasis (brain) & & na & Iwata et al. [60] \\
\hline NEC-DUE3 & & Cell line & + & Anus (sc) & Metastasis (lymph node) & & $1.0 \mu \mathrm{M}$ & Dizdar et al. [62] \\
\hline TCC-NECT-2 & & Cell line & + & Duodenal & Metastasis (ascites) & BRAF; TP53 & $3.5 \mu \mathrm{M}$ & $\begin{array}{l}\text { Yanagihara et al. } \\
{[63]}\end{array}$ \\
\hline HROC57 & + & $\begin{array}{l}\text { Spheroid } \\
\text { cell line }\end{array}$ & & Colon (lc) & Primary & BRAF & $2.1 \mu \mathrm{M}$ & Gock et al. [64] \\
\hline SS-2 & & Cell line & + & Colon & Primary & & $60 \%$ inhibition $^{\mathrm{a}}$ & Shinji et al. [61] \\
\hline
\end{tabular}

Models are organized in chronological order. If available, drug sensitivity to cisplatin is indicated. Concentrations refer to in vitro determination of IC50, $\%$ values indicate the percentage of tumor growth inhibition in vivo, except for the cell line SS-2, which was tested in vitro. GEP-NEC, gastroenteropancreatic neuroendocrine carcinoma; pdx, patient-derived xenograft. ${ }^{\text {a }}$ Oxaliplatin $(10 \mu \mathrm{M})$ was used instead of cisplatin for treatment of SS-2 cells. The CUP was negative for TTF and cdx2 markers in immunohistochemistry, suggesting potential pancreatic or non-gastroenteropancreatic origin.

eral, proliferation is low or absent, making the amount of primary tissue a major limitation for all subsequent analyses. Depending on the donor material, primary cultures provide the option to study neuroendocrine secretion and thus offer unique tools for evaluating drugs aimed at hypersecretion. Data from up to 20 primary cultures characterized their responsiveness to somatostatin analogs [72], everolimus [71, 73], trametinib, and vorinostat [32], or enzastaurin [75]. Prolonged culture times were achieved with NEN primary cells in perfused poly-dimethylsiloxane bioreactors [76]. A most promising approach to in vitro drug screening of patient-derived pNET primary cultures was developed by combining a short- to mid-term culture approach with 3D culture conditions and optimized growth factor supply. Organoids formed, which faithfully reproduce proliferation rates and differentiation characteristics of the original tumor tissue, and differentially responded to established clinical drugs, for 
example, sunitinib, everolimus, and temozolomide [74]. So far, we still lack studies that connect such in vitro drug screening of primary cultures with clinical drug responses, but in principle, they offer the prospect of personalized in vitro drug trials.

Most recently, a large set of siNET organoid cultures and several pNET cultures were reported by the group of Hans Clevers. Different from the pNET short- to midterm cultures mentioned above, these can be maintained and expanded in vitro, raising the hope that the organoid approach may finally provide the breakthrough in search for a preclinical tool to study siNET [43]. Organoid cultures from a pNET were also reported by Ichikawa et al. [42].

Organoid cultures of colorectal NEC were established as part of larger colorectal organoid collections $[59,77]$. Both phenotypic and genotypic profiling indicated a high degree of similarity with the parental tumor tissue. Most importantly, patient's drug responses in a clinical trial were matched by the drug responses in a companion trial on organoids [78].

Exciting data from a recent communication indicated that the use of tissue explants from GEP-NEN biopsies is feasible for detection of therapeutic vulnerabilities. As in pdx, such tissue explants retain the 3-dimensional architecture of the tissue and provide more faithful representation of stromal and extracellular matrix contributions. Tissue explants were successfully established from slices of 8 out of 14 liver biopsies, received drug treatment within $24 \mathrm{~h}$, and were then subjected to RNA-seq and in silico modeling for drug sensitivity and mode of action [37].

In summary, the development of model systems for culture or in vivo growth of primary NEN tissue is one of the most active and promising areas of NEN research. Combined with next-generation sequencing and the rapidly evolving powerful bioinformatics tools for data processing, these models offer unprecedented possibilities to discover clinically relevant tumor subgroups, identify drivers and vulnerabilities, and match them to therapy response in an experimental setting (please see Table 3 for a comparison of model systems). In view of shorter time frames, lower cost, the perspective to downscale the tissue requirement to biopsy size, and the relative ease of genetic manipulation, culture-based systems, such as organoids, are particularly attractive. Once validated in prospective settings, they could answer the urgent need for rational based, personalized therapy in a tumor entity that is perceived as uncommonly heterogeneous and unpredictable in its clinical course.
Genetically Modified Mouse Models of GEP-NEN

Genetically modified mice models (GEMMs) are commonly used to study human diseases and have been invaluable to oncological research, since tumors arise spontaneously in fully immunocompetent animals and develop metastases, which is an important feature of the human disease.

One drawback for developing accurate GEMMs of human sporadic NEN has been the lack of defining driver mutations. Available models mostly interrogated the role of mutations that cause familial NEN syndromes or else have addressed the roles of common oncogenes and tumor suppressors in the tissue-specific context of the neuroendocrine system. Additional NEN models became available as collateral gain from GEMM addressing islet cell biology in the context of diabetes research and, lastly, GEP-NEN emerged as pathologies in GEMMs, which were engineered as models of adenocarcinomas.

As data from sequencing efforts in large NEN cohorts emerge $[11,16,21,79,80]$, these offer the prospect of more detailed blueprints for improved models. Despite such limitations, GEMM of GEP-NEN already proved useful for understanding NEN biology as well as for preclinical translational research, including drug trials. The most commonly used genetically modified mouse models for NENs are listed in online suppl. Table 1 (see www. karger.com/doi/10.1159/000509864 for all online suppl. material) and discussed in the following sections.

\section{Men1 Deletion}

MEN comprises a group of genetically determined syndromes associated with pathologically increased cell proliferation of endocrine organs. MEN syndrome type 1 (Wermer syndrome) develops when the MEN1 gene, a tumor suppressor gene, which is localized on the long arm of chromosome 11 (11q13), loses function, which in turn predisposes to tumors of the parathyroid glands, the pituitary gland, enteropancreatic endocrine cells, lung, and thymus. GEP-NENs in these patients are typically multifocal, evolve from hyperplastic precursor lesion, and occur mostly in the pancreas or at lower frequency in the duodenum and rarely in the small intestine. Though mostly indolent, they may progress to metastatic disease. About one-third of the GEP-NENs in MEN1 are functional, with gastrin and insulin representing the most prevalent secretion products. Thus, complications such as Zollinger-Ellison syndrome occur in MEN1 patients with gastrin-secreting tumors (reviewed in [81]). In rare cases, NECs develop in the thymus. MEN1 also constitutes the most frequently mutated gene in sporadic pNEN $[11,80$, 
Table 3. Summary of strength and disadvantages of GEP-NEN models

\begin{tabular}{|c|c|c|}
\hline Type of model & Strength & Disadvantages \\
\hline GEMM & $\begin{array}{l}\text { Spontaneous tumor formation allows interrogation of all stages } \\
\text { from initiation through metastatic progression } \\
\text { Reflects organ and host-specific tumor cell stroma interactions } \\
\text { including immune cells }\end{array}$ & $\begin{array}{l}\text { Time- and cost-intensive } \\
\text { Epigenetic context of the introduced genetic alteration may } \\
\text { differ from the human disease situation } \\
\text { Variance in latency and incomplete penetrance complicate } \\
\text { drug screening } \\
\text { NEN phenotypes vary with mouse strains }\end{array}$ \\
\hline Organoids, tumoroids & $\begin{array}{l}\text { Time- and cost-efficient } \\
\text { Amenable to further genetic manipulation } \\
\text { Tumor heterogeneity initially represented } \\
\text { Easy design of drug trials } \\
\text { Culture conditions may be optimized to match the original } \\
\text { donor tissues }\end{array}$ & $\begin{array}{l}\text { At best partial representation of immune environment } \\
\text { No published reports of successful organoid/tumoroid } \\
\text { cultures of well-differentiated low-grade NEN }\end{array}$ \\
\hline Tissue slice explants & $\begin{array}{l}\text { Authentic tissue architecture and genetic background } \\
\text { Generation from biopsy size tissue samples }\end{array}$ & $\begin{array}{l}\text { Immediate processing and treatment required } \\
\text { Rapid loss of viability limits experimental time frame }\end{array}$ \\
\hline Permanent cell lines & $\begin{array}{l}\text { Unlimited supply } \\
\text { Standardized drug trials feasible } \\
\text { Ease of genetic manipulation for mechanistic studies } \\
\text { Low cost }\end{array}$ & $\begin{array}{l}\text { Combination of NET and NEC features } \\
\text { No representation of microenvironment } \\
\text { Results vary with culture conditions }\end{array}$ \\
\hline
\end{tabular}

GEP-NEN, gastroenteropancreatic neuroendocrine neoplasms; GEMM, genetically modified mice model; NET, neuroendocrine tumors; NEC, neuroendocrine carcinoma.

82]. Mice with homozygous deletion of MEN1 die at midgestation with multiple organ defects [83-85]. Heterozygous mice are however viable and develop a spectrum of tumors that is quite similar to the human syndrome with loss of the wild-type allele in the tumor tissues (reviewed in [86]). Tumor formation affects parathyroid glands, pancreatic islets, anterior pituitary, adrenal cortex, thyroids, lung (adenocarcinoma), and testes or ovaries. As seen in MEN1 patients, the pancreatic lesions in mice are multifocal and develop along a hyperplasia, adenoma, and carcinoma sequence. With respect to hormone expression, tumors in the pancreas were predominantly insulinomas, but glucagonomas, mixed hormone-producing tumors, and extrapancreatic, that is, duodenal gastrinomas were also reported, depending on the study $[83,85$, $87,88]$. The frequency of glucagon-expressing tumors in mice with heterozygous menin deletion is influenced by the genetic background, as shown by backcrossing a model of MEN1 on a mixed 129S6/SvEv and C57BL/6 background to generate congenic C57BL/6 and 129S6/SvEv strain backgrounds. Glucagon-expressing tumors accounted for almost $30 \%$ of pNEN lesions in a $129 \mathrm{~S} 6 / \mathrm{SvEv}$ background but merely $2 \%$ of pNENs in C57BL/ 6 mice, suggesting the influence of genetic modifiers that impinge on tumor cell origin, plasticity, or tumor progress. Neither the overall incidence of pNEN nor the number of insulinpositive tumors differed between the 2 strains [89].

Besides global heterozygous menin deletion, different mouse models with cell type-specific homozygous menin deletion have been generated using the Cre/LoxP system: conditional deletion of Men 1 within $\beta$-cells using the rat insulin promoter (RIP) to drive Cre expression generated insulinomas [90-92], which occurred at an earlier time point (5-12 months) than in mice with global heterozygous Men1 deletion. These $\beta$-cell-specific conditional menin knockouts are considered as suitable models closely reflecting insulinoma in humans. Mice with $\alpha$-cellspecific loss of menin exhibit excessive $\alpha$-cell hyperproliferation at very early time points, followed by formation of glucagonomas, insulinomas, and mixed tumors at 7 
months of age [93]. Subsequently, these tumors evolve into insulinomas, attesting considerable plasticity to menin-deficient $\alpha$-cells. A second model with $\alpha$-cell specific deletion of menin also features insulinomas at 13-14 months, thereby corroborating the transdifferentiation process [94]. Conversely, glucagonomas were found in aging mice with $\beta$-cell-specific menin disruption, which displayed insulinomas at young age [95].

Altogether, these phenotypes indicate that loss of MEN1 permits islet cell proliferation, reprogramming to alternative islet cell fates and subsequent tumor formation. Hence, conditional MEN1-deficient mouse models should prove excellent models to experimentally address how menin loss affects differentiation trajectories and plasticity, how these mechanisms impinge on tumor formation, and whether they may be reverted by drugs.

Work on transdifferentiation of non-transformed islet cells identified $\alpha$-cells as cell type with extraordinary plasticity [96], and $\alpha$-cell features have been attributed to MEN1-mutant sporadic pNET [15]. Moreover, pNET tissues can be stratified by distinctive enhancer profiles, which correspond to transcriptional programs resembling $\alpha$ - and $\beta$-cells [21]. Importantly, the presence of DAXX or ATRX mutations had little impact on the outcome in $\beta$-like tumors but dramatically increased the risk of disease relapse in an $\alpha$-like epigenetic background. Again, mechanistic studies in GEMM could leverage such observations for therapeutic strategies.

Though Men 1 loss of function supported lineage plasticity of islet tumor cells, tumors across different MEN1deficient mouse lines share functionality, a feature which is particularly remarkable in tumors that develop upon conditional, pdx1-driven knockout of Men1 in pancreatic precursor cells [97]. Mice undergo normal pancreatic development, but develop insulinomas within 10 months. In contrast, the exocrine pancreas remained unaffected, indicating a need for endocrine specific cofactors in tumors from MEN1-deficient cells.

Long latency, variable onset, mandatory functionality, absence of metastasis, and the occurrence of life-limiting pituitary tumors in mice with RIP-based conditional deletion of MEN1 in $\beta$-cells impede their use for modeling human sporadic pNEN. Some of these limitations were addressed in modified MEN1-deficient mouse lines. Thus, Lines et al. [98] achieved temporal control of pancreatic insulinoma formation using tamoxifen-inducible Cre recombinase to abrogate MEN1, enabling studies on tumor initiation and in vivo drug assessment [99]. The latter suggested that pNEN growth can be restricted by targeting the binding of bro- mo- and extra-terminal protein family members to acetylated histone residues.

Shorter latency periods resulted from concomitant inactivation of PTEN in compound mice generated by Wong et al. [100], demonstrating that MEN1 and PTEN function cooperatively in suppression of NEN. An exchange of the RIP transgene for a knock-in mouse insulin 1 promoter furthermore abrogated extrapancreatic tumor manifestations, enabling protracted observation of tumor-bearing mice. In the optimized model, $100 \%$ of mice had developed tumors by 13 weeks of age, allowing drug testing. Rapamycin treatment delayed tumor growth in this model, validating it from a translational perspective.

Although mice with heterozygous loss of $\mathrm{Rb}$ do not develop pNEN [101, 102], they develop a spectrum of endocrine tumors very similar to MEN1 heterozygous mice, prompting to investigate potential cooperation of both tumor suppressors in compound dual heterozygous mice. Comparable incidence and progression of tumors as well as comparable overall survival argued against cooperation $[103,104]$. This was corroborated by mutually exclusive loss of the remaining Men1 and Rb wild-type copies in the tumors, with tissue specific preference for loss of Men1 in pNEN of these mice [103]. This is consistent with the virtually exclusive distribution of MEN1 and RB mutations in human pNEN and their selective attribution to NET and NEC. Both Rb and menin affect cell growth via multiple mechanisms. Of these, effects on histone methylation may be of particular relevance for tumor suppression in endocrine tissues as endocrine tumor formation in Rb1- or Men1-deficient mice is alleviated in mice with concomitant loss of the histone demethylase $\mathrm{Kdm} 5 \mathrm{~A}$ [105].

Sundaresan et al. [106] demonstrated a role for menin in the development of gastric NEN, if combined with somatostatin deficiency. Thus, mice with villin promoter controlled deletion of the Men1 locus on a somatostatin null background (Villin-Cre: Men $1^{\mathrm{FL} / \mathrm{FL}}$; $\mathrm{Sst}^{-{ }^{-}}$) developed ECL cell derived invasive tumors of the gastric corpus, whereas the histopathology in Men 1 single knockout mice was limited to $\mathrm{G}$ cell hyperplasia and epithelial dysplasia [107]. Hypergastrinemia is discussed as critical mechanism, suggesting this model might be of relevance to MEN1 patients with Zollinger-Ellison syndrome and ECL cell tumors.

\section{ATP4A Loss of Function}

As in the Villin-Cre: Men $1^{\mathrm{FL} / \mathrm{FL}}$ mice mentioned above, the phenotype of mice with ATP4A (ATPase $\mathrm{H}^{+} / \mathrm{K}^{+}$transporting subunit alpha) is characterized by hypergastrin- 
emia. ATP4A loss-of-function mutations impair the function of the parietal cell proton pump and hence result in achlorhydria, which in turn causes hypergastrinemia and leads to ECL cell hyperplasia [10]. Patients from affected families develop an atypical form of gastric NET. Mice carrying a knock-in of the corresponding ATP4A (R703C) mutation recapitulated the early onset gastric hypoacidity and hypergastrinemia. Consequently, the architecture of gastric glands deteriorated and severe hyperplasia, dysplasia, and glandular metaplasia occurred [108]. Unlike their human counterpart, the mice do not develop NEN. Nonetheless, they already provided valuable mechanistic clues regarding the relative functional contribution of achlorhydria and hypergastrinemia to the premalignant changes of the gastric glands. Thus, premalignant lesions were partly reversed by acidification of the drinking water, even though hypergastrinemia continued, pointing toward dominance of hypoacidity. ATP4A mice may therefore serve as valuable tools for prevention trials in conditions of achlorhydria and hypergastrinemia.

\section{Vhl Deletion}

VHL syndrome is an inherited disorder associated with highly vascularized tumors arising in multiple organs, including hemangioblastomas, clear cell renal cell carcinoma, pheochromocytoma/paraganglioma, serous cystadenomas, and pNEN. VHL is caused by mutations of the VHL tumor suppressor localized on the short arm of chromosome 3 (recently reviewed in [109]). While homozygous loss of Vhl in mice is lethal, Shen et al. [110] established 3 different cell-specific Vhl knockouts in the pancreas (GluCre, Rip-Cre, and Pdx1-Cre). It turned out that deletion of Vhl does not affect the function of the endocrine pancreas and loss of Vhl in differentiated $\alpha$-cells or $\beta$-cells was not associated with pNET. In contrast, inactivation of Vhl in pancreatic progenitor cells caused early postnatal lethality, most likely due to impaired function of the exocrine pancreas. In surviving mice, the pancreas was largely replaced by fat at 16 months, but microcystic adenomas and islet hyperplasia characterized the remaining glandular tissue. The authors speculate that adenomas arise from the exocrine pancreatic compartment, for example, ductal or centroacinar cells, and concluded that these models will help to further define molecular mechanisms involved in VHL-associated pancreatic diseases [110].

\section{Constitutively Active Akt}

The phosphatidylinositol 3-kinase/Akt pathway is part of the mTOR network, which is frequently deregulated in pNEN $[11,80]$. In line, sustained expression of dominant active myrAkt1 under an RIP promoter caused hypertrophy of $\beta$-cell mass and development of insulinomas at 12 months [111]. Insulinomas can be invasive and display a metastatic phenotype. Of note, Akt inhibitors were proposed as novel therapeutics for NET [112], emphasizing the translational value of such mouse models.

\section{c-Myc Activation}

Activation of $\mathrm{c}-\mathrm{Myc}$ in adult $\beta$-cells induces proliferation but also leads to an excess of apoptosis, thereby preventing carcinogenesis. By crossing mice constitutively overexpressing the apoptosis inhibitor Bcl-xL and mice overexpressing an inducible variant of $\mathrm{c}-\mathrm{Myc}$ under the RIP promoter (pIns-c-MycERTAM/RIP-Bcl-xL), Pelengaris et al. [113] presented a very interesting model of insulinoma. Upon induction of c-myc, these mice display rapid $\beta$-cell hyperplasia and unusually aggressive, poorly differentiated insulinomas develop even within 6 weeks. Lymphatic and hematogenous metastases follow at later times. When induction of c-Myc is stopped, the phenotype is completely reversible. Notably, this model only poorly reflects pathophysiological processes associated with insulinoma and/or PNET in humans. Nevertheless, the authors concluded that even highly complex tumors can be induced and maintained by only 2 interlocked molecular lesions [113].

\section{Disruption of Glucagon Signaling}

GEMMs with alterations in glucagon signaling were originally generated to assess the potential benefits of glucagon ablation in diabetes $[114,115]$. Knockout of the glucagon receptor (GCGR) $[114,116]$, deletion of prohormone convertase 2 (PC2) [117], and replacement of glucagon by a glucagon/green fluorescent protein (GFP) knock-in allele [118] were strategies pursued for disruption of glucagon signaling. All strategies produced islet hyperplasia due to a dramatic increase of glucagon-positive cells. Hyperplastic islets frequently contained minor populations of cells expressing somatostatin or pancreatic polypeptide, multihormonal cells coexpressing insulin and glucagon $[114,116-119]$, or coexpression of markers for mature and precursor cells (glucagon and pdx1, respectively), suggestive of relaxed lineage commitment. Glucagon expression was moreover noted in scattered cells of pancreatic ducts adjacent to hyperplastic islets $[114,116,117]$, suggesting that putative stem cells in the ductal compartment are recruited to increase $\alpha$-cell mass, as has been shown in models of $\beta$-cell regeneration following injury $[120,121]$. Hyperplastic changes were reversed by glucagon substitution in PC2 mice, in line 
with an adaptive function. Left untreated, hyperplastic islets of PC2 knockout mice progressed to dysplastic lesions, adenomas, and invasive carcinomas with occasional areas of anaplastic cells. Similarly, glucagon receptor knockout mice developed by Yu et al. [116] featured dysplastic lesions and finally overt NEN in 10- to 12-monthold mice, with loss of hormone expression in a portion of the tumors. Metastases were absent $[114,117]$ or rare (1/14 mice [116]). Macroscopic metastases occurred at higher frequencies in mice with replacement of proglucagon [118]. Screening of these mice for micrometastases based on GFP expression documented full penetrance of liver involvement and lung lesions in $>90 \%$ of mice. Intriguingly, tumor growth remained dependent on endocrine factors produced specifically in the glucagon/GFP mice, as allograft transplanted tumors proliferated in these mice, but not in proglucagon proficient wild-type mice [118].

As tools for studying NEN, mice with disrupted glucagon signaling offer an ideally suited model for Mahvash disease, a rare familial pNET syndrome caused by biallelic inactivating mutations of the glucagon receptor gene. The models also have benefits for studying sporadic pNEN, because invasive carcinomas arise without need for an artificial oncogene such as simian virus 40 (SV40). However, the profound metabolic changes that initiate these pNENs lack a tangible correlate in sporadic NEN and apart from an implication of menin loss - the transformation process remains undefined. Identification of participating mechanisms should be feasible and informative for sporadic pNEN and future model use, which offers the critical benefit of producing metastatic disease.

Another interesting feature of these NEN models is the implication of ductal cells with putative stem cell characteristics. The existence of adult pancreatic stem cells in humans has been a matter of debate and, consequently, there are no data to support development of pNEN from a ductal stem cell compartment in humans at this time. Recently, however, bona fide stem cells residing in pancreatic ducts have been reported [122, 123]. Thus, their role in pancreatic endocrine adaptation and transformation will hopefully be elucidated in the near future.

Finally, the relaxed lineage commitment of the islet tumors with coexpression of $\alpha$ - and $\beta$-lineage markers is a feature of some sporadic pNEN as well as aging normal pancreatic islet cells $[21,124]$. Similarly, the nonfunctioning tumors that occasionally arose have a counterpart in human sporadic NEN. Models with disrupted glucagon action may thus be suitable to address the role of lineage plasticity and dedifferentiation in pNEN.
Deletion of $\mathrm{p} 53$ and Components of $\mathrm{Rb}$ Complexes

As mentioned above, mice with global heterozygous loss of RB1 feature pituitary adenomas and medullary thyroid carcinomas but no GEP-NEN [101, 102, 125], which is consistent with the absence of RB1 mutations in human NET [126]. In contrast, alterations of RB1 and TP53 genes have become recognized as a common feature of GEP-NEC, irrespective of their tissue of origin, and are shared with neuroendocrine carcinomas outside the digestive system such as SCLC and neuroendocrine prostate cancer. The tumor incidence and spectrum of p53and $\mathrm{Rb}$-deficient mice were first examined more than 2 decades ago [102, 125]. While global loss of p53 increased tumor incidence in both homozygous and heterozygous mice, the tumor spectrum did not include GEP-NEN. Notably, mice deficient for both $\mathrm{Rb}$ and $\mathrm{p} 53$ showed earlier tumor development and de novo incidence of pancreatic islet carcinomas, suggesting additive effects of p53 and $\mathrm{Rb}$ in endocrine tumors $[102,125]$. In line with these phenotypes from global knockout mice, a conditional ablation of p53 and $\mathrm{Rb}$ in endocrine cells with active renin promoter produced $\mathrm{pNEN}$ as defining pathology and primary cause of morbidity. Small glucagon-producing tumors in this model emerged at 3 months and rapidly progressed with up to $40 \%$ of mice harboring hepatic metastasis and premature death in a majority of mice around 8 months of age. Flanking lineage tracing experiments, in which the renin promoter construct controlled expression of fluorescent reporters, confirmed renin promoter activity in the developing pancreas and pinpointed $\alpha$-cell precursors as likely cells of origin for glucagonoma formation. On the one hand, the model recapitulates human sporadic glucagonomas and may be useful for studying the response to targeted therapies $[127,128]$. On the other hand, the underlying genetic alterations and the aggressive course recommend these mice as a model for pancreatic NEC [25]. Interestingly, SV40 large T antigen (SV40-Tag) driven by the same promoter yielded kidney and subcutaneous tumors and low frequency adrenal and testicular neoplasia, but only occasionally pancreatic tumors $[127,129]$. It remains open, whether full ablation of $\mathrm{p} 53$, of $\mathrm{Rb}$, or the combination thereof permits full penetrance of glucagonoma formation. Both tumor suppressors act via multiple mechanisms, which are only in part compromised by SV40-Tag. One overlapping mechanism is the ability of SV40 to disrupt pRb/E2F-dependent cell cycle control. pRb/E2F-dependent control of proliferation is similarly defective in mice with enhanced cdk4 activity due to a cdk4(R24C) missense mutation [130], which abrogates regulation by the $\mathrm{cdk}$ inhibitor p16. Fit- 
tingly, almost one-third of these mice develop pNENs as part of a more diverse spectrum of tumors including mesenchymous, pituitary, and Leydig cell tumors.

Overexpression of polyoma middle $\mathrm{T}$ (PyMT) has been used as a surrogate for activation of oncogenic signaling pathways (e.g., mTOR, MAPK, or HIPPO signaling). When conditionally expressed in $\beta$-cells, PyMT causes hyperplasia. An additional loss of $\mathrm{p} 53$ and p16/p19 in $\beta$-cells individually and cooperatively induced pNETs. If conditional expression of PyMT is directed to pancreatic precursors via control by the pdx1 promoter [131], additional acinar cell carcinomas arise, albeit at low frequency (10\%). Deletion of p53 in the progenitor model induced full penetrance of metastatic acinar cell carcino$\mathrm{ma}$, a phenotype that remained unchanged by co-deletion of p16/p19 [132]. Much in contrast, long latency pNET developed upon exclusive deletion of p16/p19 in pdx1 progenitor cells. Together, these findings supported a causal role of p16/p19 in pNEN, at least in a background of PyMT. In earlier models, the TVA receptor for avian leukosis sarcoma virus subgroup A under the control of the elastase promoter was used for delivery of avian retrovirus-bearing PyMT or c-Myc to acinar cells in newborn mice. Of note, amphicrine phenotypes with coexpression of chymotrypsin and synaptophysin emerged upon postnatal acinar cell-specific PyMT expression in a background of either p53 or p16/p19 deficiency [133, 134], supporting a permissive role for both tumor suppressors in the acquisition of NE features in otherwise acinar tumors. By comparison, the virus delivery of cMyc to the acinar cell compartment of p16/19-deficient mice led to the exclusive development of well-differentiated insulinomas [133], a finding that further supports the contribution of p16/19 inactivation for neuroendocrine differentiation and furthermore an oncogenic function of c-Myc that either depends on or causes endocrine lineage differentiation.

A permissive role of $\mathrm{p} 53$ deficiency in neuroendocrine differentiation is also suggested from models testing the cooperative action of p53 loss and chronic inflammation in the pancreas. More specifically, conditional expression of cyclooxygenase-2 or I $\mathrm{B}$ kinase-2 (to induce chronic inflammation) as well as conditional loss of p53 were driven by the elastase promoter and were therefore restricted to acinar cells [135]. Despite this acinar origin, mixed carcinomas of different histologic subtypes emerged, including acinar cell carcinoma, ductal adenocarcinoma, poorly differentiated tumors with sarcomatoid features, and NEC, all of which retained wild-type $\mathrm{K}$-ras. This suggests that NEC may arise from dedifferen- tiation or transdifferentiation of adult exocrine cells in a setting of chronic injury and implicates p53 in the acquisition of neuroendocrine features. Conversely, injury by caerulein-induced pancreatitis had formerly been shown to render $\beta$-cells susceptible to K-ras induced transformation, resulting in transdifferentiation to PanIN lesions [136]. As there is little clinical evidence for a role of chronic inflammatory injury in pNEN, it remains speculative, whether the chronic injury model translates to human NEC. Notably, though, sequencing of 25 colorectal NEC revealed a subgroup with $\mathrm{p} 53$, but no Rb mutation, which contained tumors from patients with ulcerative colitis [137]. Occasional pNENs were also noted in mouse models that exhibit a broad spectrum of multiple tumors from different lineages, for example, peroxiredoxin 1 knockout mice [138] or mice with deletion of the Cul9 E3 ubiquitin ligase [139]. Moreover, rare poorly differentiated NECs of either small or large intestine have been described in aging mice with conditional loss of $\mathrm{Rb}$ in intestine, urothelium, and prostate controlled by the fatty acid-binding protein promoter [140].

Indeed, the overall picture that emerges from these often sophisticated GEMMs emphasizes an intricate interplay of lineage specificity and plasticity when interrogating the role of defined genetic alterations -at least - in pNEN. This may reflect the extraordinary lineage plasticity in the pancreas or equally apply to NEN arising in other locations of the gastroenteropancreatic system. Although at times confusing, these diverse NEN phenotypes advance our understanding of the cellular origin of NEN, as they can be linked to distinct spatiotemporal patterns of oncogene or tumor suppressor functions. From a practical perspective, though, many models are of limited use, since NENs constitute only a minor fraction of tumors arising and do not limit the morbidity and mortality of the mice.

\section{Human Papillomavirus}

High-risk human papillomavirus (HR-HPV) was recently found in anorectal NEC without mutations in TP53 or RB1, suggesting HR-HPV infection as an alternative mechanism of E2F deregulation in NEC [141]. In line with such a mechanism, gastric NEC with full penetrance arise in mice with expression of HPV-16 early region under the control of the bovine keratin 6 promoter [142].

Altogether, most of the GEMMs described above give rise to $\mathrm{pNET}$, produce functioning tumors within $>6$ through $>12$ months, and lack metastasis. Thus, there remains an unmet need for models of nonfunctional, well 
differentiated but metastatic pNET as well as for midgut tumors. Human sporadic pNETs segregate into subgroups characterized by differentiation features of either $\alpha$ - or $\beta$-islet cells, and a recurrent theme is a more adverse prognosis in patients with $\alpha$-like features. This raises the question whether targeting of transgenes to $\alpha$-cells might yield more aggressive models than use of the RIP system. Another layer of complexity relates to the timing of transgene expression. Thus, sporadic MEN1 mutations in humans were largely confined to $a$-like pNET, but a cohort of patients with MEN1 syndrome exhibited no enrichment of $\alpha$-like tumors. Perhaps, inducible strategies in adult $\alpha$-cells and/or combination with DAXX/ATRX inactivation will be required for more metastatic models. A mouse line that allows tamoxifen-inducible Cre expression in a-cells and enteroendocrine L-cells without disrupting preproglucagon gene expression has recently become available (Gcg-CreER $\left.{ }^{\mathrm{T} 2}[143]\right)$.

Present models with full penetrance have already been used for drug trials $[97,99,100]$, and these settings offer the unique opportunity to address the role of the immune system in the development of well-differentiated pNETs and their response to treatments. This applies even more to GEMMs representing NEC, which also allow the study of metastatic disease [144] along physiologic routes in an immune competent setting, a clear advantage when compared to injection of permanent cell lines in xenograft metastasis models. Apart from such emerging translational applications, GEMMs that model the genetic landscape of GEP-NENs will remain invaluable tools for understanding their pathobiology.

SV40-Based Transgenic Mouse Models

Preceding the GEMMs with alterations in NEN-related genes, transgenic mice with overexpression of the SV40-Tag under control of endocrine-specific or epithelial promoters have provided a range of models for NEN.

\section{SV40-Tag Expression Controlled by Endocrine}

Promoters

The RIP-Tag mouse model, in which the RIP drives the expression of Tag specifically in islet cells and $\beta$-cells become highly proliferative, represents one of the beststudied models in the context of GEP-NEN [145-147]. While several different lines were tested over the years, the RIP1-Tag2 and RIP1-Tag5 lines are most commonly used [145, 147-150]. RIP1-Tag2 mice feature early expression of Tag with $\beta$-cell hyperplasia occurring at 8 weeks and die prematurely at $\approx 9-12$ weeks due to hypoglycemia. Mice fed with a high-carbohydrate diet survive longer and develop multiple insulinomas at approximately 10 weeks, which progress to highly invasive islet cell carcinomas [145]. Tumors in RIP1-Tag2 mice display an aggressive phenotype with heavy tumor load, but few lymphatic metastases and rare hepatic (micro)metastases $[118,151]$. Though SV 40-Tag expression is detected in all islets of RIP1-Tag2 mice, $<2 \%$ of islets progress to islet carcinomas, suggesting the contribution of additional transforming events. At the mechanistic level, the SV40 Tag viral oncoprotein acts via inactivation of $\mathrm{p} 53$ and $\mathrm{Rb}$. RIP1-Tag2 mice exhibit residual Rb activity, though, since reduced latency and increased insulinoma burden were found upon added conditional deletion of $\mathrm{Rb}$ [152].

RIP1-Tag mice constitute one of the pioneer transgenic models of cancer with impact far beyond the biology of NEN. They have been instrumental for developing concepts of tumor angiogenesis and for translating them into clinical therapies [146]. Data from RIP1-Tag2 mice also implicated the innate immune system in the progression of pNEN, as depletion of tumor-associated macrophages prevented angiogenesis and transformation of hyperplastic islet into invasive carcinoma [153]. RIP1-Tag2 mice also develop poorly differentiated NEC, although at much lower frequencies than insulinomas [154].

RIP1-Tag2 mice represent an excellent model for studying highly vascular malignant insulinomas. Their well-defined stepwise progression with concomitant neoangiogenesis uniquely qualified RIP1-Tag2 mice for use in preclinical intervention trials [146]. Thus, results from drug trials with everolimus and sunitinib in RIP1-Tag2 mice anticipated the positive outcome of subsequent clinical trials in sporadic NEN [155-159] even though sporadic human tumors lack an obvious correlate to the welldefined multistep sequence of tumor initiation and progression in RIP1-Tag2 mice. Possibly, an accurate representation of the tumor microenvironment of sporadic (p)NET in RIP1-Tag2 is the determinant that accounts for the good predictive capacity of preclinical trials in mice. Indeed, work on the RIP1-Tag2 model has highlighted the importance of the tumor microenvironment for mechanisms of resistance to antiangiogenic therapies and for strategies to circumvent resistance (reviewed in [160-162]). The latter include combined therapies with additional targeting of c-met [163], PDL-1 [164], or mTOR [165], suggesting such combinations might also benefit patients with pNET.

In RIP1-Tag5 mice, $\mathrm{T}$ antigen expression is observed somewhat later at 10 weeks and insulinoma develop by 25 weeks of age. Of note, RIP1-Tag5 mice display a strong activation of the immune system against the $\mathrm{T}$ antigen; 
thus, many experts have proposed these mice as a model to study the role of immune-related processes in the development of NEN $[148,149]$.

Progression of insulinomas to invasive carcinomas varied with different genetic backgrounds of RIP1-Tag2 mice [166]. Following up on genetic linkage analysis, the anaplastic lymphoma kinase (ALK) emerged as a driver of invasiveness in the C57BL/6 background when compared to $\mathrm{C} 3 \mathrm{HeB} / \mathrm{Fe}$ mice.

Crossing mice from a C57BL/6 to other inbred mice strains also yielded variants of the RIP1-Tag2 model, which more closely match the biology of human sporadic NENs. Thus, nonfunctioning pNENs with hepatic metastases develop in an AB6 [167] or B6A [168] genetic background. Despite the high similarity of the AB6 and BA6 genetic background, phenotypes of the 2 strains differed: RIP1-Tag2 mice exhibit reduced pancreatic tumor load and metastases as well as de novo occurrence of siNEN specifically in the BA6 background, implicating imprinted genes in these phenotypic traits. Fittingly, a loss of imprinting with increased expression of the IGF2 gene was found in human siNET tissue samples. Moreover, decreased gene dosage of the IGF2 inhibitory interaction partner IGFBP1 in RIP1-Tag2/Igfbp1 ${ }^{(+/-)}$mice recapitulated the development of siNEN lesions, and phenocopied the reduction of pancreatic and hepatic tumor load observed in the B6A background [168].

Different genetic backgrounds can hence be exploited to better understand and modify the spectrum and behavior of NEN. Such modifications may answer specific needs in preclinical research, for example, representation of hepatic metastasis or midgut NET.

As described above, RIP1-Tag2 mice do not regularly develop tumors in the small intestine in a C57BL/6 background, although occasional lesions have been reported [169]. However, small intestinal cancers with almost complete penetrance were obtained upon combined expression of SV40-Tag with polyoma small T $[169,170]$. Secretin production as well as early invasive and metastatic growth were characteristics of these small intestinal carcinomas. The permanent murine STC1 cell line was derived from these mice and has been used to model siNEN in vitro.

In several other experimental approaches, combined intestinal and pancreatic tumors developed due to control of SV40-Tag expression by promoters that were active in both enteroendocrine and islet cells. For instance, mice with Tag expression driven by the secretin promoter exhibited pancreatic insulinomas that resembled the tumors of RIP-Tag mice. In addition, NET with glucagon or secretin expression formed in the proximal colon. In contrast to these well-differentiated tumors, lesions in the small intestine were less differentiated as judged by immunoreactivity to neuron-specific enolase and the neural marker PGP9.5 but not enteroendocrine hormones. Finally, lymphoid-like neoplasias devoid of neural or endocrine markers occurred in liver, spleen, and thymus, suggestive of a non-neuroendocrine origin [171].

Different portions of the rat preproglucagon promoter were employed to direct SV40-Tag to islets and enteroendocrine cells. In their initial study, Efrat et al. [172] used an 850-bp fragment, which drove expression of the Tag in $a$-cells of the endocrine pancreas and distinct neuron populations. Mice revealed stepwise progression from $\alpha$-cell hyperplasia to dysplastic lesions and glucagonomas, including invasive and metastatic tumors. Abundant expression of neuroendocrine markers characterized benign lesions, but not an invasive carcinoma with concurrent metastasis that had formed [173], a finding that is reminiscent of the poorly differentiated islet carcinomas arising at minor frequency in RIP1-Tag2 mice [154].

A different tumor spectrum developed when SV40 expression was driven from a larger, $2.5-\mathrm{kb}$ fragment of the preproglucagon promoter [174]. Intestinal tumors dominated the phenotype of these GluTag-Y mice, which suffered from invasive and metastatic, often, plurihormonal carcinomas, which became apparent by 4 weeks of age. Body weight was reduced to almost half compared to littermate controls and transgenic mice succumbed to premature death between 4 and 12 weeks. In the pancreas, hyperplastic islets composed of large pleomorphic cells had developed by 4 weeks and progressed to tumors in mice surviving the subsequent weeks $[174,175]$. Despite expression of SV40-Tag in neuroendocrine cells of the small intestine and stomach, neither hyperplastic nor neoplastic lesion occurred there. Pancreatic islet tumors with similarity to RIP1-Tag2 mice plus pituitary tumors were observed in mice with SV40-Tag expression controlled by the vasopressin promoter [176].

Taken together, most phenotypes of mice with targeting of SV40-Tag to enteroendocrine or islet cells are remarkable for their diversity with respect to differentiation, functionality, and aggressiveness, both within 1 line and in between lines. Furthermore, closely related enteroendocrine cells apparently exhibited inherent susceptibility or resistance to the same oncogenic challenge. In retrospect, these diverse phenotypes may be in part explained by expression of SV40-Tag at different stages of lineage commitment, either en route to enteroendocrine differentiation from intestinal stem cells or during development 
of the pancreas. Combined with these specific contexts of oncogene induction, SV40-Tag expression itself in turn likely affected lineage specific differentiation programs, thereby further supporting tumor heterogeneity.

SV40-Tag Expression Controlled by Non-Endocrine Promoters

Interestingly, NENs have been observed in murine models that were initially developed for other purposes and used non-neuroendocrine promoters for targeting of SV40-Tag to specific gastroenteropancreatic tissues. Insulinomas were described along with different hepatobiliary tumors in transgenic mice expressing the SV40-Tag under a human gastrin promoter [177] or with brain tumors when using the Moloney murine sarcoma virus promoter [178]).

Similarly, invasive acinar carcinoma, D-cell hyperplasia, and (less frequently) insulinomas were observed when expressing SV40 T antigen under a rat elastase 1 promoter [179], while insulinomas developed along with hepatocellular carcinoma (HCC) in transgenic mice overexpressing the large and small SV40 $\mathrm{T}$ antigens under a murine metallothionein-I promoter [180]. A combination of HCC and islet cell carcinoma was also seen when SV40Tag was controlled by the L-type pyruvate kinase (L-PK) promoter. Islet cell carcinomas but not HCC lesions were diet dependent in this model, in line with regulation of the L-PK promoter by insulin and glucagon [181].

Poorly differentiated carcinomas were initiated by targeting SV40-Tag to different intestinal epithelia: Syder et al. [182] placed the SV40-Tag under conditional control of Atp $4 b$ (noncatalytic $\beta$-subunit of $\mathrm{H}, \mathrm{K}$-ATPase) and thereby directed it to committed non-neuroendocrine parietal cell precursors. They observed small cell cancers in over half of these mice by 48 weeks with metastatic spread to lymph nodes or liver [182]. Transcriptomes of the invasive cancer cells documented an induction of neurogenic transcription factors on the one hand and of transcription factors that maintain an undifferentiated state, such as Sox 2 or Hey, on the other hand, when compared to non-transformed preparietal cells.

A second model with full penetrance of NEC utilized the intestinal trefoil factor promoter for SV40-Tag expression in colonic goblet cells [183]. Instead of mucinous adenocarcinoma, multifocal, rapidly dividing aggressive small cell cancer of the proximal colon caused premature death at 10-12 weeks of age. Transgene expression was also seen in conjunction with enlarged and dysplastic villi in the duodenum, but none of these progressed to tumor formation.
As above, the neuroendocrine phenotype came as an unexpected finding in multifocal, morphologically undifferentiated gastric carcinomas induced by SV40-Tag under control of the carcinoembryonic antigen (CEA) minimal promoter. Carcinomas progressed rapidly and ultimately caused premature death around 115 days [184]. Transcriptome analyses of tumors from these CEA424SV40-Tag mice confirmed the expression of neurogenic transcription factors and marker genes, with partial overlap to published signatures from NEN in ATP4B mutant mice. Follow-up studies on an NEC cell line generated from a CEA424-SV40-Tag tumor indicated that the neuroendocrine signature required continued expression of the SV40-Tag. This finding suggested that the neuroendocrine phenotype resides in the mechanisms of transformation rather than in a preexistent neuroendocrine commitment of the cell of origin. By means of inducible lineage tracing of LGR5-positive adult stem cells in the CEA424-SV40-Tag model, the origin of the neuroendocrine carcinomas was more directly addressed. Results clearly separated SV40-Tag and LGR5 expression, respectively, consistent with long-lived pre-enteroendocrine precursor cells or reserve stem cells as putative tumor originating cells [185].

While the above models exhibit dominant NE differentiation, carcinomas with either epithelial or NE marker expression were observed in aging Vil-Cre-ER(T2) $\times$ LoxP-Tag mice [186]. In the absence of tamoxifen, Tag expression depended on stochastic activation of Cre recombinase in intestinal (stem) cells with active villin promoter, resulting in long latency of tumor formation and concurrent host immune response. Single tumor lesions with either glandular differentiation or undifferentiated morphology and synaptophysin expression developed. Both morphologies were observed either separate or mixed within 1 lesion, suggesting either parallel development from a common precursor or transdifferentiation between the 2 phenotypes. Based on the above features, Vil-Cre-ER(T2) $\times$ LoxP-Tag mice would be uniquely suited to model NEC and mixed neuroendocrine neoplasias. Unfortunately, the long and variably latency period in the range of 20 months counterbalances these advantages.

\section{Conclusion}

Recent advances in the molecular characterization of NEN identified novel molecular subtypes that might explain the different clinical characteristics of NEN, their distinct sensitivities to treatment, and the variable pa- 
tients' prognosis. Transferring this novel knowledge into animal models might help to assess the relevance of different mutations and genetic alterations for the pathophysiology of human disease. As epigenetic mechanisms emerge as driving forces of NEN, modeling this epigenetic reprogramming constitutes 1 major challenge to be met. Immunocompetent rodent cancer models have the advantage over cell-based models (e.g., organoids) to allow characterization of stroma and immune responses as well as immune-oncological therapies, while they may not accurately reflect all mutational patterns observed in human patients. Complementary to mouse models, recapitulating GEP-NENs in patient-derived culture systems and xenografts could provide new platforms, enabling us to reconstruct the oncogenic steps leading to GEP-NEN development.

\section{Conflict of Interest Statement}

The authors have no conflicts of interest to declare.

\section{Funding Sources}

Supported by a grant from the WILL FOUNDATION, Berlin, to B.W., a gift by G. Speidel to B.W., and a generous donation in memoriam "Sören Piepgras" by Dr. M.G. to B.W.

\section{Author Contributions}

All authors were involved in writing and designing the manuscript. All authors have read and approved the manuscript.

\section{References}

1 Dasari A, Shen C, Halperin D, Zhao B, Zhou $\mathrm{S}, \mathrm{Xu} \mathrm{Y}$, et al. Trends in the incidence, prevalence, and survival outcomes in patients with neuroendocrine tumors in the United States. JAMA Oncol. 2017 Oct 1;3(10):1335-42.

2 Dasari A, Mehta K, Byers LA, Sorbye H, Yao JC. Comparative study of lung and extrapulmonary poorly differentiated neuroendocrine carcinomas: a SEER database analysis of 162,983 cases. Cancer. 2018 Feb 15;124(4): 807-15.

3 Milione M, Maisonneuve P, Spada F, Pellegrinelli A, Spaggiari P, Albarello L, et al. The clinicopathologic heterogeneity of grade 3 gastroenteropancreatic neuroendocrine neoplasms: morphological differentiation and proliferation identify different prognostic categories. Neuroendocrinology. 2017; 104(1):85-93.

4 Sorbye H, Welin S, Langer SW, Vestermark LW, Holt N, Osterlund P, et al. Predictive and prognostic factors for treatment and survival in 305 patients with advanced gastrointestinal neuroendocrine carcinoma (WHO G3): the NORDIC NEC study. Ann Oncol. 2013;24(1): 152-60.

5 Mafficini A, Scarpa A. Genetics and epigenetics of gastroenteropancreatic neuroendocrine neoplasms. Endocr Rev. 2019 Apr 1; 40(2):506-36.

6 Crona J, Skogseid B. GEP-NETS UPDATE: genetics of neuroendocrine tumors. Eur J Endocrinol. 2016 Jun;174(6):R275-90.

7 Dreijerink KMA, Timmers HTM, Brown M. Twenty years of menin: emerging opportunities for restoration of transcriptional regulation in MEN1. Endocr Relat Cancer. 2017 Oct;24(10):T135-145.

8 Sei Y, Zhao X, Forbes J, Szymczak S, Li Q, Trivedi A, et al. A hereditary form of small intestinal carcinoid associated with a germ- line mutation in inositol polyphosphate multikinase. Gastroenterology. 2015 Jul;149(1): 67-78.

9 Dumanski JP, Rasi C, Björklund P, Davies H, Ali AS, Grönberg M, et al. A MUTYH germline mutation is associated with small intestinal neuroendocrine tumors. Endocr Relat Cancer. 2017 Aug;24(8):427-43.

10 Calvete O, Reyes J, Zuñiga S, PaumardHernández B, Fernández V, Bujanda L, et al. Exome sequencing identifies ATP4A gene as responsible of an atypical familial type I gastric neuroendocrine tumour. Hum Mol Genet. 2015 May 15;24(10):2914-22.

11 Jiao Y, Shi C, Edil BH, de Wilde RF, Klimstra DS, Maitra A, et al. DAXX/ATRX, MEN1, and mTOR pathway genes are frequently altered in pancreatic neuroendocrine tumors. Science. 2011 Mar 4;331(6021):1199-203.

12 Scarpa A, Chang DK, Nones K, Corbo V, Patch AM, Bailey P, et al. Whole-genome landscape of pancreatic neuroendocrine tumours. Nature. 2017 Feb 15;543(7643):65.

13 Heaphy CM, de Wilde RF, Jiao Y, Klein AP, Edil BH, Shi C, et al. Altered telomeres in tumors with ATRX and DAXX mutations. Science. 2011 Jul 22;333(6041):425.

14 Marinoni I, Kurrer AS, Vassella E, Dettmer M, Rudolph T, Banz V, et al. Loss of DAXX and ATRX are associated with chromosome instability and reduced survival of patients with pancreatic neuroendocrine tumors. Gastroenterology. 2014 Feb;146(2):453-60.e5.

15 Chan CS, Laddha SV, Lewis PW, Koletsky MS, Robzyk K, Da Silva E, et al. ATRX, DAXX or MEN1 mutant pancreatic neuroendocrine tumors are a distinct alpha-cell signature subgroup. Nat Commun. 2018 Oct 12;9(1):4158.

16 Alvarez MJ, Subramaniam PS, Tang LH, Grunn A, Aburi M, Rieckhof G, et al. A precision oncology approach to the pharmacologi- cal targeting of mechanistic dependencies in neuroendocrine tumors. Nat Genet. $2018 \mathrm{Jul}$; 50(7):979-89.

17 Banck MS, Kanwar R, Kulkarni AA, Boora GK, Metge F, Kipp BR, et al. The genomic landscape of small intestine neuroendocrine tumors. J Clin Invest. 2013 Jun;123(6):2502-8.

18 Francis JM, Kiezun A, Ramos AH, Serra S, Pedamallu CS, Qian ZR, et al. Somatic mutation of CDKN1B in small intestine neuroendocrine tumors. Nat Genet. 2013 Dec;45(12): 1483-6.

19 Karpathakis A, Dibra H, Pipinikas C, Feber A, Morris T, Francis J, et al. Progressive epigenetic dysregulation in neuroendocrine tumour liver metastases. Endocr Relat Cancer. 2017 Feb;24(2):L21-25.

20 Karpathakis A, Dibra H, Pipinikas C, Feber A, Morris T, Francis J, et al. Prognostic impact of novel molecular subtypes of small intestinal neuroendocrine tumor. Clin Cancer Res. 2016 Jan 1;22(1):250-8.

21 Cejas P, Drier Y, Dreijerink KMA, Brosens LAA, Deshpande V, Epstein CB, et al. Enhancer signatures stratify and predict outcomes of non-functional pancreatic neuroendocrine tumors. Nat Med. 2019;25(8):12605.

22 Tang LH, Basturk O, Sue JJ, Klimstra DS. A practical approach to the classification of WHO grade 3 (G3) well-differentiated neuroendocrine tumor (WD-NET) and poorly differentiated neuroendocrine carcinoma (PDNEC) of the pancreas. Am J Surg Pathol. 2016 Sep;40(9):1192-202.

23 Konukiewitz B, Jesinghaus $M$, Steiger K, Schlitter AM, Kasajima A, Sipos B, et al. Pancreatic neuroendocrine carcinomas reveal a closer relationship to ductal adenocarcinomas than to neuroendocrine tumors G3. Hum Pathol. 2018 Jul;77:70-9. 
24 Woischke C, Schaaf CW, Yang HM, Vieth M, Veits L, Geddert H, et al. In-depth mutational analyses of colorectal neuroendocrine carcinomas with adenoma or adenocarcinoma components. Mod Pathol. 2017 Jan;30(1):95-103.

25 Kawasaki K, Fujii M, Sato T. Gastroenteropancreatic neuroendocrine neoplasms: genes, therapies and models. Dis Model Mech. 2018 11(2):029595.

26 Evers BM, Townsend CM Jr, Upp JR, Allen E, Hurlbut SC, Kim SW, et al. Establishment and characterization of a human carcinoid in nude mice and effect of various agents on tumor growth. Gastroenterology. 1991;101(2): 303-11.

27 Kaku M, Nishiyama T, Yagawa K, Abe M. Establishment of a carcinoembryonic antigenproducing cell line from human pancreatic carcinoma. Gan. 1980;71(5):596-601.

28 Kölby L, Bernhardt P, Ahlman H, Wängberg $\mathrm{B}$, Johanson V, Wigander A, et al. A transplantable human carcinoid as model for somatostatin receptor-mediated and amine transporter-mediated radionuclide uptake. Am J Pathol. 2001;158(2):745-55.

29 Gueli N, Toto A, Palmieri G, Carmenini G, Delpino A, Ferrini U. In vitro growth of a cell line originated from a human insulinoma. Exp Clin Cancer Res. 1987 Jan 01;6:281-5.

30 Pfragner R, Behmel A, Höger H, Beham A, Ingolic E, Stelzer I, et al. Establishment and characterization of three novel cell lines - PSTS, L-STS, H-STS - derived from a human metastatic midgut carcinoid. Anticancer Res. 2009 Jun;29(6):1951-61.

31 Tillotson LG, Lodestro C, Höcker M, Wiedenmann B, Newcomer CE, Reid LM. Isolation, maintenance, and characterization of human pancreatic islet tumor cells expressing vasoactive intestinal peptide. Pancreas. 2001; 22(1):91-8.

32 Hofving T, Arvidsson Y, Almobarak B, Inge L, Pfragner R, Persson M, et al. The neuroendocrine phenotype, genomic profile and therapeutic sensitivity of GEPNET cell lines. Endocr Relat Cancer. 2018 Mar;25(3):367-80.

33 Grozinsky-Glasberg S, Shimon I, Rubinfeld $\mathrm{H}$. The role of cell lines in the study of neuroendocrine tumors. Neuroendocrinology. 2012;96(3):173-87.

34 Benten D, Behrang Y, Unrau L, Weissmann V, Wolters-Eisfeld G, Burdak-Rothkamm S, et al. Establishment of the first well-differentiated human pancreatic neuroendocrine tumor model. Mol Cancer Res. 2018 Mar;16(3): 496-507.

35 Boora GK, Kanwar R, Kulkarni AA, Pleticha J, Ames M, Schroth G, et al. Exome-level comparison of primary well-differentiated neuroendocrine tumors and their cell lines. Cancer Genet. 2015 Jul-Aug;208(7-8):374-81.

36 Vandamme T, Beyens M, Peeters M, Van Camp G, de Beeck KO. Next generation exome sequencing of pancreatic neuroendocrine tumor cell lines BON-1 and QGP-1 reveals different lineages. Cancer Genet. 2015 Oct;208(10):523.
37 Alvarez MJ, Yan P, Alpaugh ML, Bowden M, Sicinska E, Zhou CW, et al. Reply to "H-STS, L-STS and KRJ-I are not authentic GEPNET cell lines". Nat Genet. 2019 Oct;51(10):1427-8.

38 Hidalgo M, Amant F, Biankin AV, Budinská E, Byrne AT, Caldas C, et al. Patient-derived xenograft models: an emerging platform for translational cancer research. Cancer Discov. 2014;4(9):998-1013.

39 Gao H, Korn JM, Ferretti S, Monahan JE, Wang Y, Singh M, et al. High-throughput screening using patient-derived tumor xenografts to predict clinical trial drug response. Nat Med. 2015;21(11):1318-25.

40 Choi Y, Lee S, Kim K, Kim S-H, Chung Y-J, Lee C. Studying cancer immunotherapy using patient-derived xenografts (PDXs) in humanized mice. Exp Mol Med. 2018;50(8):0180115.

41 Ben-David U, Ha G, Tseng Y-Y, Greenwald NF, Oh C, Shih J, et al. Patient-derived xenografts undergo mouse-specific tumor evolution. Nat Genet. 2017;49(11):1567-75.

42 Ichikawa YA, Hiroshima Y, Kobayashi N, Masuda Y, Goto A, Tokuhisa M, et al. Establishment of patient-derived tumor organoid (PDTO) derived from pancreatic neuroendocrine tumor. Neuroendocrinology. 2019; 108(Suppl 1):1-273,

43 Dayton T, Den Hartigh L, McFaline JL, Van Leeuwaarde R, Valk GD, Van den Berg J, et al. Using adult stem cell-derived organoids to model neuroendocrine neoplasms. Neuroendocrinology. 2019;108(Suppl 1):1-273,

44 Yang Z, Zhang L, Serra S, Law C, Wei A, Stockley TL, et al. Establishment and characterization of a human neuroendocrine tumor xenograft. Endocr Pathol. 2016 Jun;27(2):97103.

45 Krampitz GW, George BM, Willingham SB, Volkmer J-P, Weiskopf K, Jahchan N, et al. Identification of tumorigenic cells and therapeutic targets in pancreatic neuroendocrine tumors. Proc Natl Acad Sci U S A. 2016 Apr 19;113(16):4464-9.

46 Chamberlain CE, German MS, Yang K, Wang J, VanBrocklin H, Regan M, et al. A Patientderived xenograft model of pancreatic neuroendocrine tumors identifies sapanisertib as a possible new treatment for everolimus-resistant tumors. Mol Cancer Ther. 2018 Dec; 17(12):2702-9.

47 Quinn LA, Moore GE, Morgan RT, Woods LK. Cell lines from human colon carcinoma with unusual cell products, double minutes, and homogeneously staining regions. Cancer Res. 1979 Dec;39(12):4914-24.

48 Lundqvist M, Mark J, Funa K, Heldin NE, Morstyn G, Wedell B, et al. Characterisation of a cell line (LCC-18) from a cultured human neuroendocrine-differentiated colonic carcinoma. Eur J Cancer. 1991;27(12):1663-8.

49 Fujiwara T, Motoyama T, Ishihara N, Watanabe H, Kumanishi T, Kato K, et al. Characterization of four new cell lines derived from small-cell gastrointestinal carcinoma. Int $\mathrm{J}$ Cancer. 1993 Jul 30;54(6):965-71.
50 Aizawa K, Tanaka N, Yabusaki H, Suzuki S, Muto I, Nishimaki T, et al. Chemotherapy of human small-cell gastrointestinal carcinoma xenografts in nude mice. Surg Oncol. 1995 Jun;4(3):139-45.

51 Konno H, Arai T, Tanaka T, Baba M, Matsumoto K, Kanai T, et al. Antitumor effect of a neutralizing antibody to vascular endothelial growth factor on liver metastasis of endocrine neoplasm. Jpn J Cancer Res. 1998 Sep;89(9): 933-9.

52 Tanaka N, Onda M, Seya T, Kanazawa Y, Naito Z, Asano G, et al. Establishment and characterization of a human rectal neuroendocrine carcinoma xenograft into nude mice. Digestion. 1999 Mar-Apr;60(2):117-24.

53 Takahashi Y, Onda M, Tanaka N, Seya T. Establishment and characterization of two new rectal neuroendocrine cell carcinoma cell lines. Digestion. 2000;62(4):262-70.

54 Koizumi M, Onda M, Tanaka N, Seya T, Yamada T, Takahashi Y. Antiangiogenic effect of octreotide inhibits the growth of human rectal neuroendocrine carcinoma. Digestion. 2002;65(4):200-6.

55 Yachida S, Zhong Y, Patrascu R, Davis MB, Morsberger LA, Griffin CA, et al. Establishment and characterization of a new cell line, A99, from a primary small cell carcinoma of the pancreas. Pancreas. 2011 Aug;40(6):90510.

56 Krieg A, Mersch S, Boeck I, Dizdar L, Weihe E, Hilal Z, et al. New model for gastroenteropancreatic large-cell neuroendocrine carcinoma: establishment of two clinically relevant cell lines. PLoS One. 2014;9(2):e88713.

57 Jiang J, Wang DD, Yang M, Chen D, Pang L, Guo $\mathrm{S}$, et al. Comprehensive characterization of chemotherapeutic efficacy on metastases in the established gastric neuroendocrine cancer patient derived xenograft model. Oncotarget. 2015 Jun 20;6(17):15639-51.

58 Okumura T, Shimada Y, Omura T, Hirano K, Nagata T, Tsukada K. MicroRNA profiles to predict postoperative prognosis in patients with small cell carcinoma of the esophagus. Anticancer Res. 2015 Feb;35(2):719-27.

59 Fujii M, Shimokawa M, Date S, Takano A, Matano M, Nanki K, et al. A colorectal tumor organoid library demonstrates progressive loss of niche factor requirements during tumorigenesis. Cell Stem Cell. 2016 Jun 2;18(6): $827-38$

60 Iwata $\mathrm{R}$, Maruyama M, Ito T, Nakano $\mathrm{Y}$, Kanemura Y, Koike T, et al. Establishment of a tumor sphere cell line from a metastatic brain neuroendocrine tumor. Med Mol Morphol. 2017 Dec;50(4):211-9.

61 Shinji S, Sasaki N, Yamada T, Koizumi M, Ohta R, Matsuda A, et al. Establishment and characterization of a novel neuroendocrine carcinoma cell line derived from a human ascending colon tumor. Cancer Sci. 2019 Dec; 110(12):3708-17.

Detjen/Hammerich/Özdirik/Demir/ Wiedenmann/Tacke/Jann/Roderburg 
62 Dizdar L, Drusenheimer J, Werner TA, Möhlendick B, Schütte SC, Esposito I, et al. Establishment and characterization of a novel cell line derived from a small cell neuroendocrine carcinoma of the anal canal. Neuroendocrinology. 2018;107(3):246-56.

63 Yanagihara K, Kubo T, Mihara K, Kuwata T, Ochiai A, Seyama T, et al. Establishment of a novel cell line from a rare human duodenal poorly differentiated neuroendocrine carcinoma. Oncotarget. 2018 Nov 23;9(92):3650314.

64 Gock M, Mullins CS, Harnack C, Prall F, Ramer R, Göder A, et al. Establishment, functional and genetic characterization of a colon derived large cell neuroendocrine carcinoma cell line. World J Gastroenterol. 2018 Sep 7; 24(33):3749-59.

65 Yachida S, Vakiani E, White CM, Zhong Y, Saunders T, Morgan R, et al. Small cell and large cell neuroendocrine carcinomas of the pancreas are genetically similar and distinct from well-differentiated pancreatic neuroendocrine tumors. Am J Surg Pathol. 2012 Feb; 36(2):173-84.

66 Girardi DM, Silva ACB, Rêgo JFM, Coudry RA, Riechelmann RP. Unraveling molecular pathways of poorly differentiated neuroendocrine carcinomas of the gastroenteropancreatic system: a systematic review. Cancer Treat Rev. 2017 May;56:28-35.

67 Dizdar L, Werner TA, Drusenheimer JC, Mohlendick B, Raba K, Boeck I, et al. BRAF(V600E) mutation: a promising target in colorectal neuroendocrine carcinoma. Int J Cancer. 2019 Mar 15;144(6):1379-90.

68 Yanagihara K, Kubo T, Iino Y, Mihara K, Morimoto C, Seyama T, et al. Development and characterization of a cancer cachexia model employing a rare human duodenal neuroendocrine carcinoma-originating cell line. Oncotarget. 2019 Mar 29;10(25):243550.

69 Ohmoto A, Suzuki M, Takai E, Rokutan H, Fujiwara Y, Morizane C, et al. Establishment of preclinical chemotherapy models for gastroenteropancreatic neuroendocrine carcinoma. Oncotarget. 2018 Apr 20;9(30):2108699.

70 Mullins CS, Micheel B, Matschos S, Leuchter M, Bürtin F, Krohn M, et al. Integrated biobanking and tumor model establishment of human colorectal carcinoma provides excellent tools for preclinical research. Cancers. 2019 Oct 9;11(10): 11

71 Falletta S, Partelli S, Rubini C, Nann D, Doria A, Marinoni I, et al. mTOR inhibitors response and mTOR pathway in pancreatic neuroendocrine tumors. Endocr Relat Cancer. 2016 Nov;23(11):883-91.

72 Mohamed A, Blanchard MP, Albertelli M, Barbieri F, Brue T, Niccoli P, et al. Pasireotide and octreotide antiproliferative effects and sst2 trafficking in human pancreatic neuroendocrine tumor cultures. Endocr Relat Cancer. 2014 Oct;21(5):691-704.
73 Mohamed A, Romano D, Saveanu A, Roche C, Albertelli M, Barbieri F, et al. Anti-proliferative and anti-secretory effects of everolimus on human pancreatic neuroendocrine tumors primary cultures: is there any benefit from combination with somatostatin analogs? Oncotarget. 2017 Jun 20;8(25):4104463.

74 April-Monn SL, Wiedmer T, Magdalena S, Maire RS, Schiavo Lena M, Trippel M, et al. 3D primary cell culture: a novel preclinical model for pancreatic neuroendocrine tumors (PanNETs). Neuroendocrinology. 2020 Apr 3.

75 Mole D, Gagliano T, Gentilin E, Tagliati F, Pasquali C, Ambrosio MR, et al. Targeting protein kinase $\mathrm{C}$ by enzastaurin restrains proliferation and secretion in human pancreatic endocrine tumors. Endocr Relat Cancer. 2011 Aug;18(4):439-50.

76 Herring B, Whitt J, Aweda T, Ou J, Guenter $\mathrm{R}$, Lapi S, et al. A growth model of neuroendocrine tumor surrogates and the efficacy of a novel somatostatin-receptor-guided antibody-drug conjugate: perspectives on clinical response? Surgery. 2020;167(1):197-203.

77 Sato T, Stange DE, Ferrante M, Vries RG, Van Es JH, Van den Brink S, et al. Long-term expansion of epithelial organoids from human colon, adenoma, adenocarcinoma, and Barrett's epithelium. Gastroenterology. 2011 Nov; 141(5):1762-72.

78 Vlachogiannis G, Hedayat S, Vatsiou A, Jamin Y, Fernández-Mateos J, Khan K, et al. Patient-derived organoids model treatment response of metastatic gastrointestinal cancers. Science. 2018;359(6378):920-6.

79 Wang H, Bender A, Wang P, Karakose E, Inabnet WB, Libutti SK, et al. Insights into beta cell regeneration for diabetes via integration of molecular landscapes in human insulinomas. Nat Commun. 2017 Oct 3;8(1):767.

80 Scarpa A, Chang DK, Nones K, Corbo V, Patch AM, Bailey P, et al. Whole-genome landscape of pancreatic neuroendocrine tumours. Nature. 2017 Mar 2;543(7643):65-71.

81 Thakker RV. Multiple endocrine neoplasia type 1 (MEN1) and type 4 (MEN4). Mol Cell Endocrinol. 2014 Apr 5;386(1-2):2-15.

82 Toliat MR, Berger W, Ropers HH, Neuhaus P, Wiedenmann B. Mutations in the MEN I gene in sporadic neuroendocrine tumours of gastroenteropancreatic system. Lancet. 1997 Oct 25;350(9086):1223.

83 Bertolino P, Radovanovic I, Casse H, Aguzzi A, Wang ZQ, Zhang CX. Genetic ablation of the tumor suppressor menin causes lethality at mid-gestation with defects in multiple organs. Mech Dev. 2003 May;120(5):549-60.

84 Fontaniere S, Duvillie B, Scharfmann R, Carreira $C$, Wang ZQ, Zhang CX. Tumour suppressor menin is essential for development of the pancreatic endocrine cells. J Endocrinol. 2008 Nov; 199(2):287-98.
85 Crabtree JS, Scacheri PC, Ward JM, GarrettBeal L, Emmert-Buck MR, Edgemon KA, et al. A mouse model of multiple endocrine neoplasia, type 1 , develops multiple endocrine tumors. Proc Natl Acad Sci U S A. 2001 Jan 30; 98(3):1118-23.

86 Agarwal SK. Exploring the tumors of multiple endocrine neoplasia type 1 in mouse models for basic and preclinical studies. Int J Endocr Oncol. 2014;1(2):153-61.

87 Bertolino P, Tong WM, Galendo D, Wang ZQ, Zhang CX. Heterozygous Men1 mutant mice develop a range of endocrine tumors mimicking multiple endocrine neoplasia type 1. Mol Endocrinol. 2003 Sep;17(9):1880-92.

88 Harding B, Lemos MC, Reed AA, Walls GV, Jeyabalan J, Bowl MR, et al. Multiple endocrine neoplasia type 1 knockout mice develop parathyroid, pancreatic, pituitary and adrenal tumours with hypercalcaemia, hypophosphataemia and hypercorticosteronaemia. Endocr Relat Cancer. 2009 Dec;16(4):1313-27.

89 Lines KE, Javid M, Reed AAC, Walls GV, Stevenson $M$, Simon $M$, et al. Genetic background influences tumour development in heterozygous Men1 knockout mice. Endocr Connect. 2020 May;9(5):426-37.

90 Crabtree JS, Scacheri PC, Ward JM, McNally SR, Swain GP, Montagna C, et al. Of mice and MEN1: insulinomas in a conditional mouse knockout. Mol Cell Biol. 2003 Sep;23(17): 6075-85.

91 Bertolino P, Tong WM, Herrera PL, Casse H, Zhang CX, Wang ZQ. Pancreatic beta-cellspecific ablation of the multiple endocrine neoplasia type 1 (MEN1) gene causes full penetrance of insulinoma development in mice. Cancer Res. 2003 Aug 15;63(16):4836-41.

92 Biondi CA, Gartside MG, Waring P, Loffler KA, Stark MS, Magnuson MA, et al. Conditional inactivation of the MEN1 gene leads to pancreatic and pituitary tumorigenesis but does not affect normal development of these tissues. Mol Cell Biol. 2004 Apr;24(8):312531.

93 Lu J, Herrera PL, Carreira C, Bonnavion R, Seigne C, Calender A, et al. Alpha cell-specific Men1 ablation triggers the transdifferentiation of glucagon-expressing cells and insulinoma development. Gastroenterology. 2010 May;138(5):1954-65.

94 Shen HC, Ylaya K, Pechhold K, Wilson A, Adem A, Hewitt SM, et al. Multiple endocrine neoplasia type 1 deletion in pancreatic alphacells leads to development of insulinomas in mice. Endocrinology. 2010 Aug;151(8):402430.

95 Li F, Su Y, Cheng Y, Jiang X, Peng Y, Li Y, et al. Conditional deletion of Men1 in the pancreatic $\beta$-cell leads to glucagon-expressing tumor development. Endocrinology. 2015 Jan; 156(1):48-57.

96 Bramswig NC, Everett LJ, Schug J, Dorrell C, Liu C, Luo Y, et al. Epigenomic plasticity enables human pancreatic $\alpha$ to $\beta$ cell reprogramming. J Clin Invest. 2013 Mar;123(3):127584. 
97 Shen HC, He M, Powell A, Adem A, Lorang D, Heller C, et al. Recapitulation of pancreatic neuroendocrine tumors in human multiple endocrine neoplasia type I syndrome via Pdx1-directed inactivation of Men1. Cancer Res. 2009 Mar 1;69(5):1858-66.

98 Lines KE, Vas Nunes RP, Frost M, Yates CJ, Stevenson M, Thakker RV. A MEN1 pancreatic neuroendocrine tumour mouse model under temporal control. Endocr Connect. 2017 May;6(4):232-42.

99 Lines KE, Stevenson M, Filippakopoulos P, Müller S, Lockstone HE, Wright B, et al. Epigenetic pathway inhibitors represent potential drugs for treating pancreatic and bronchial neuroendocrine tumors. Oncogenesis. 2017 May 15;6(5):e332.

100 Wong C, Tang LH, Davidson C, Vosburgh E, Chen W, Foran DJ, et al. Two well-differentiated pancreatic neuroendocrine tumor mouse models. Cell Death Differ. 2019 Jun 3;27:269-83.

101 Jacks T, Fazeli A, Schmitt EM, Bronson RT, Goodell MA, Weinberg RA. Effects of an Rb mutation in the mouse. Nature. 1992 Sep 24; 359(6393):295-300.

102 Harvey M, Vogel H, Lee EY, Bradley A, Donehower LA. Mice deficient in both p53 and $\mathrm{Rb}$ develop tumors primarily of endocrine origin. Cancer Res. 1995 Mar 1;55(5):114651.

103 Matoso A, Zhou Z, Hayama R, Flesken-Nikitin A, Nikitin AY. Cell lineage-specific interactions between Men 1 and $\mathrm{Rb}$ in neuroendocrine neoplasia. Carcinogenesis. 2008 Mar;29(3):620-8.

104 Loffler KA, Biondi CA, Gartside MG, Serewko-Auret MM, Duncan R, Tonks ID, et al. Lack of augmentation of tumor spectrum or severity in dual heterozygous Men1 and Rb1 knockout mice. Oncogene. 2007 Jun 7;26(27):4009-17.

105 Lin W, Cao J, Liu J, Beshiri ML, Fujiwara Y, Francis J, et al. Loss of the retinoblastoma binding protein 2 (RBP2) histone demethylase suppresses tumorigenesis in mice lacking Rb1 or Men1. Proc Natl Acad Sci U S A. 2011 Aug 16;108(33):13379-86.

106 Sundaresan S, Kang AJ, Hayes MM, Choi EK, Merchant JL. Deletion of Men1 and somatostatin induces hypergastrinemia and gastric carcinoids. Gut. 2017 Jun;66(6): 1012-21.

107 Veniaminova NA, Hayes MM, Varney JM, Merchant JL. Conditional deletion of menin results in antral G cell hyperplasia and hypergastrinemia. Am J Physiol Gastrointest Liver Physiol. 2012 Sep 15;303(6):G752-64.

108 Calvete O, Varro A, Pritchard DM, Barroso A, Oteo M, Morcillo MÁ, et al. A knockin mouse model for human ATP4aR703C mutation identified in familial gastric neuroendocrine tumors recapitulates the premalignant condition of the human disease and suggests new therapeutic strategies. Dis Model Mech. 2016 Sep 1;9(9):975-84.
109 Nordstrom-O'Brien M, van der Luijt RB, van Rooijen E, van den Ouweland AM, Majoor-Krakauer DF, Lolkema MP, et al. Genetic analysis of von Hippel-Lindau disease. Hum Mutat. 2010 May;31(5):521-37.

110 Shen HC, Adem A, Ylaya K, Wilson A, He $M$, Lorang D, et al. Deciphering von HippelLindau (VHL/Vhl)-associated pancreatic manifestations by inactivating $\mathrm{Vhl}$ in specific pancreatic cell populations. PLoS One. 2009;4(4):e4897.

111 Alliouachene S, Tuttle RL, Boumard S, Lapointe T, Berissi S, Germain S, et al. Constitutively active Akt1 expression in mouse pancreas requires S6 kinase 1 for insulinoma formation. J Clin Invest. 2008 Nov; 118(11):3629-38.

112 Wolin EM. PI3K/Akt/mTOR pathway inhibitors in the therapy of pancreatic neuroendocrine tumors. Cancer Lett. 2013 Jul 10; 335(1):1-8.

113 Pelengaris S, Khan M, Evan GI. Suppression of Myc-induced apoptosis in beta cells exposes multiple oncogenic properties of Myc and triggers carcinogenic progression. Cell. 2002 May 3;109(3):321-34.

114 Gelling RW, Du XQ, Dichmann DS, Romer J, Huang H, Cui L, et al. Lower blood glucose, hyperglucagonemia, and pancreatic alpha cell hyperplasia in glucagon receptor knockout mice. Proc Natl Acad Sci U S A. 2003 Feb 4;100(3):1438-43.

115 Parker JC, Andrews KM, Allen MR, Stock JL, McNeish JD. Glycemic control in mice with targeted disruption of the glucagon receptor gene. Biochem Biophys Res Commun. 2002 Jan 18;290(2):839-43.

116 Yu R, Dhall D, Nissen NN, Zhou C, Ren SG. Pancreatic neuroendocrine tumors in glucagon receptor-deficient mice. PLoS One. 2011;6(8):e23397.

117 Jones HB, Reens J, Brocklehurst SR, Betts CJ, Bickerton S, Bigley AL, et al. Islets of Langerhans from prohormone convertase-2 knockout mice show $\alpha$-cell hyperplasia and tumorigenesis with elevated $\alpha$-cell neogenesis. Int J Exp Pathol. 2014 Feb;95(1):29-48.

118 Takano Y, Kasai K, Takagishi Y, Kikumori T, Imai T, Murata Y, et al. Pancreatic neuroendocrine tumors in mice deficient in proglucagon-derived peptides. PLoS One. 2015;10(7): 0133812.

119 Vuguin PM, Kedees MH, Cui L, Guz Y, Gelling RW, Nejathaim M, et al. Ablation of the glucagon receptor gene increases fetal lethality and produces alterations in islet development and maturation. Endocrinology. 2006 Sep;147(9):3995-4006

120 Bonner-Weir S, Inada A, Yatoh S, Li WC, Aye T, Toschi E, et al. Transdifferentiation of pancreatic ductal cells to endocrine betacells. Biochem Soc Trans. 2008 Jun;36(Pt 3): 353-6.

121 El-Gohary Y, Wiersch J, Tulachan S, Xiao X, Guo P, Rymer C, et al. Intraislet pancreatic ducts can give rise to insulin-positive cells. Endocrinology. 2016 Jan;157(1):166-75.
122 Loomans CJM, Williams Giuliani N, Balak J, Ringnalda F, van Gurp L, Huch M, et al. Expansion of adult human pancreatic tissue yields organoids harboring progenitor cells with endocrine differentiation potential. Stem Cell Rep. 2018 Mar 13;10(3):712-24.

123 Qadir MMF, Álvarez-Cubela S, Klein D, Lanzoni G, García-Santana C, Montalvo A, et al. P2RY1/ALK3-expressing cells within the adult human exocrine pancreas are BMP-7 expandable and exhibit progenitorlike characteristics. Cell Rep. 2018 Feb 27; 22(9):2408-20.

124 Enge M, Arda HE, Mignardi M, Beausang J, Bottino R, Kim SK, et al. Single-cell analysis of human pancreas reveals transcriptional signatures of aging and somatic mutation patterns. Cell. 2017 Oct 5;171(2):321-e14.

125 Williams BO, Remington L, Albert DM, Mukai S, Bronson RT, Jacks T. Cooperative tumorigenic effects of germline mutations in $\mathrm{Rb}$ and p53. Nat Genet. 1994 Aug;7(4): $480-4$.

126 Scarpa A. The landscape of molecular alterations in pancreatic and small intestinal neuroendocrine tumours. Ann Endocrinol. 2019 Jun;80(3):153-8.

127 Glenn ST, Jones CA, Sexton S, LeVea CM, Caraker SM, Hajduczok G, et al. Conditional deletion of p53 and Rb in the renin-expressing compartment of the pancreas leads to a highly penetrant metastatic pancreatic neuroendocrine carcinoma. Oncogene. 2014 Dec 11;33(50):5706-15.

128 Yu R. Animal models of spontaneous pancreatic neuroendocrine tumors. Mol Cell Endocrinol. 2016 Feb 5;421:60-7.

129 Sigmund CD, Okuyama K, Ingelfinger J, Jones CA, Mullins JJ, Kane C, et al. Isolation and characterization of renin-expressing cell lines from transgenic mice containing a renin-promoter viral oncogene fusion construct. J Biol Chem. 1990 Nov 15;265(32): 19916-22.

130 Sotillo R, Dubus P, Martín J, de la Cueva E, Ortega S, Malumbres M, et al. Wide spectrum of tumors in knock-in mice carrying a Cdk4 protein insensitive to INK4 inhibitors. EMBO J. 2001 Dec 3;20(23):6637-47.

131 Du YC, Klimstra DS, Varmus H. Activation of PyMT in beta cells induces irreversible hyperplasia, but oncogene-dependent acinar cell carcinomas when activated in pancreatic progenitors. PLoS One. 2009 Sep 7; 4(9):e6932.

132 Azzopardi S, Pang S, Klimstra DS, Du YN p53 and p16(Ink4a)/p19(Arf) loss promotes different pancreatic tumor types from PyMT-expressing progenitor cells. Neoplasia. 2016 Oct;18(10):610-7.

133 Lewis BC, Klimstra DS, Varmus HE. The cmyc and PyMT oncogenes induce different tumor types in a somatic mouse model for pancreatic cancer. Genes Dev. 2003 Dec 15; 17(24):3127-38. 
134 Morton JP, Klimstra DS, Mongeau ME, Lewis BC. Trp53 deletion stimulates the formation of metastatic pancreatic tumors. Am J Pathol. 2008 Apr;172(4):1081-7.

135 Swidnicka-Siergiejko AK, Gomez-Chou SB, Cruz-Monserrate Z, Deng D, Liu Y, Huang $\mathrm{H}$, et al. Chronic inflammation initiates multiple forms of K-Ras-independent mouse pancreatic cancer in the absence of TP53. Oncogene. 2017 Jun 1;36(22):314958.

136 Gidekel Friedlander SY, Chu GC, Snyder EL, Girnius N, Dibelius G, Crowley D, et al. Context-dependent transformation of adult pancreatic cells by oncogenic K-Ras. Cancer Cell. 2009 Nov 6;16(5):379-89.

137 Shamir ER, Devine WP, Pekmezci M, Umetsu SE, Krings G, Federman S, et al. Identification of high-risk human papillomavirus and $\mathrm{Rb} / \mathrm{E} 2 \mathrm{~F}$ pathway genomic alterations in mutually exclusive subsets of colorectal neuroendocrine carcinoma. Mod Pathol. 2019;32(2):290-305.

138 Neumann CA, Krause DS, Carman CV, Das S, Dubey DP, Abraham JL, et al. Essential role for the peroxiredoxin Prdx1 in erythrocyte antioxidant defence and tumour suppression. Nature. 2003 Jul 31;424(6948): 561-5.

139 Pei XH, Bai F, Li Z, Smith MD, Whitewolf G, Jin R, et al. Cytoplasmic CUL9/PARC ubiquitin ligase is a tumor suppressor and promotes p53-dependent apoptosis. Cancer Res. 2011 Apr 15;71(8):2969-77.

140 Parisi T, Bronson RT, Lees JA. Inactivation of the retinoblastoma gene yields a mouse model of malignant colorectal cancer. Oncogene. 2015 Nov 26;34(48):5890-9.

141 Shamir ER, Devine WP, Pekmezci M, Umetsu SE, Krings G, Federman S, et al. Identification of high-risk human papillomavirus and $\mathrm{Rb} / \mathrm{E} 2 \mathrm{~F}$ pathway genomic alterations in mutually exclusive subsets of colorectal neuroendocrine carcinoma. Mod Pathol. 2019 Feb;32(2):290-305.

142 Searle PF, Thomas DP, Faulkner KB, Tinsley JM. Stomach cancer in transgenic mice expressing human papillomavirus type 16 early region genes from a keratin promoter. J Gen Virol. 1994 May;75(Pt 5):1125-37.

143 Ackermann AM, Zhang J, Heller A, Briker A, Kaestner KH. High-fidelity glucagonCreER mouse line generated by CRISPRCas9 assisted gene targeting. Mol Metab. 2017 Mar;6(3):236-44.

144 Glenn ST, Jones CA, Sexton S, LeVea CM, Caraker SM, Hajduczok G, et al. Conditional deletion of $\mathrm{p} 53$ and $\mathrm{Rb}$ in the renin-expressing compartment of the pancreas leads to a highly penetrant metastatic pancreatic neuroendocrine carcinoma. Oncogene. 2013 Dec 02;33(50):5706.

145 Hanahan D. Heritable formation of pancreatic beta-cell tumours in transgenic mice expressing recombinant insulin/simian virus 40 oncogenes. Nature. 1985 May 9-15; 315(6015):115-22.
146 Tuveson D, Hanahan D. Translational medicine: cancer lessons from mice to humans. Nature. 2011 Mar 17;471(7338):316-7.

147 Singh M, Couto SS, Forrest WF, Lima A, Cheng JH, Molina R, et al. Anti-VEGF antibody therapy does not promote metastasis in genetically engineered mouse tumour models. J Pathol. 2012 Aug;227(4):417-30.

148 Adams TE, Alpert S, Hanahan D. Non-tolerance and autoantibodies to a transgenic self antigen expressed in pancreatic beta cells. $\mathrm{Na}$ ture. 1987 Jan 15-21;325(6101):223-8.

149 Onrust SV, Hartl PM, Rosen SD, Hanahan D. Modulation of L-selectin ligand expression during an immune response accompanying tumorigenesis in transgenic mice. J Clin Invest. 1996 Jan 1;97(1):54-64.

150 Zumsteg A, Strittmatter K, Klewe-Nebenius D, Antoniadis H, Christofori G. A bioluminescent mouse model of pancreatic beta-cell carcinogenesis. Carcinogenesis. 2010 Aug. 31(8):1465-74.

151 Paez-Ribes M, Allen E, Hudock J, Takeda T, Okuyama H, Vinals F, et al. Antiangiogenic therapy elicits malignant progression of tumors to increased local invasion and distant metastasis. Cancer Cell. 2009 Mar 3;15(3): 220-31.

152 Casanovas O, Hager JH, Chun MG, Hanahan $\mathrm{D}$. Incomplete inhibition of the $\mathrm{Rb}$ tumor suppressor pathway in the context of inactivated p53 is sufficient for pancreatic islet tumorigenesis. Oncogene. 2005 Oct 6; 24(44):6597-604.

153 Krug S, Abbassi R, Griesmann H, Sipos B, Wiese D, Rexin P, et al. Therapeutic targeting of tumor-associated macrophages in pancreatic neuroendocrine tumors. Int J Cancer. 2018 Oct 1;143(7):1806-16.

154 Hunter KE, Quick ML, Sadanandam A, Hanahan D, Joyce JA. Identification and characterization of poorly differentiated invasive carcinomas in a mouse model of pancreatic neuroendocrine tumorigenesis. PLoS One. 2013;8(5):e64472.

155 Casanovas O, Hicklin DJ, Bergers G, Hanahan $\mathrm{D}$. Drug resistance by evasion of antiangiogenic targeting of VEGF signaling in late-stage pancreatic islet tumors. Cancer Cell. 2005 Oct;8(4):299-309.

156 Raymond E, Dahan L, Raoul JL, Bang YJ, Borbath I, Lombard-Bohas C, et al. Sunitinib malate for the treatment of pancreatic neuroendocrine tumors. N Engl J Med. 2011 Feb 10;364(6):501-13.

157 Pavel ME, Hainsworth JD, Baudin E, Peeters M, Hörsch D, Winkler RE, et al. Everolimus plus octreotide long-acting repeatable for the treatment of advanced neuroendocrine tumours associated with carcinoid syndrome (RADIANT-2): a randomised, placebo-controlled, phase 3 study. Lancet. 2011 Dec 10;378(9808):2005-12.

158 Yao JC, Shah MH, Ito T, Bohas CL, Wolin EM, Van Cutsem E, et al. Everolimus for advanced pancreatic neuroendocrine tumors. N Engl J Med. 2011 Feb 10;364(6):514-23.
159 Chiu CW, Nozawa H, Hanahan D. Survival benefit with proapoptotic molecular and pathologic responses from dual targeting of mammalian target of rapamycin and epidermal growth factor receptor in a preclinical model of pancreatic neuroendocrine carcinogenesis. J Clin Oncol. 2010 Oct 10; 28(29):4425-33.

160 Mazzone M, Bergers G. Regulation of blood and lymphatic vessels by immune cells in tumors and metastasis. Annu Rev Physiol. 2019 Feb 10;81:535-60.

161 Bergers G, Hanahan D. Modes of resistance to anti-angiogenic therapy. Nat Rev Cancer. 2008 Aug;8(8):592-603.

162 Jayson GC, Kerbel R, Ellis LM, Harris AL Antiangiogenic therapy in oncology: current status and future directions. Lancet. 2016 Jul 30;388(10043):518-29.

163 Sennino B, Ishiguro-Oonuma $\mathrm{T}$, Wei $\mathrm{Y}$, Naylor RM, Williamson CW, Bhagwandin $\mathrm{V}$, et al. Suppression of tumor invasion and metastasis by concurrent inhibition of $\mathrm{c}$ Met and VEGF signaling in pancreatic neuroendocrine tumors. Cancer Discov. 2012 Mar;2(3):270-87.

164 Allen E, Jabouille A, Rivera LB, Lodewijckx I, Missiaen R, Steri V, et al. Combined antiangiogenic and anti-PD-L1 therapy stimulates tumor immunity through HEV formation. Sci Transl Med. 2017 Apr 12;9(385):9.

165 Allen E, Miéville P, Warren CM, Saghafinia $\mathrm{S}$, Li L, Peng MW, et al. Metabolic symbiosis enables adaptive resistance to anti-angiogenic therapy that is dependent on mTOR signaling. Cell Rep. 2016 May 10;15(6): 1144-60.

166 Chun MG, Mao JH, Chiu CW, Balmain A, Hanahan D. Polymorphic genetic control of tumor invasion in a mouse model of pancreatic neuroendocrine carcinogenesis. Proc Natl Acad Sci U S A. 2010 Oct 5;107(40): 17268-73.

167 Kobayashi S, Contractor T, Vosburgh E, Du YN, Tang LH, Clausen R, et al. Alleles of Insm1 determine whether RIP1-Tag2 mice produce insulinomas or nonfunctioning pancreatic neuroendocrine tumors. Oncogenesis. $2019 \mathrm{Feb} 22 ; 8(3): 16$.

168 Contractor T, Clausen R, Harris G, Rosenfeld J, Carpizo D, Tang L, et al. IGF2 drives formation of ileal neuroendocrine tumors in patients and mice. Endocr Relat Cancer. 2020 Jan 1;ERC-19-0505.R1.

169 Grant SG, Seidman I, Hanahan D, Bautch VL. Early invasiveness characterizes metastatic carcinoid tumors in transgenic mice. Cancer Res. 1991 Sep 15;51(18):4917-23.

170 Rindi G, Grant SG, Yiangou Y, Ghatei MA, Bloom SR, Bautch VL, et al. Development of neuroendocrine tumors in the gastrointestinal tract of transgenic mice. Heterogeneity of hormone expression. Am J Pathol. 1990 Jun;136(6):1349-63. 
171 Lopez MJ, Upchurch BH, Rindi G, Leiter $\mathrm{AB}$. Studies in transgenic mice reveal potential relationships between secretin-producing cells and other endocrine cell types. J Biol Chem. 1995 Jan 13;270(2):885-91.

172 Efrat S, Teitelman G, Anwar M, Ruggiero D, Hanahan D. Glucagon gene regulatory region directs oncoprotein expression to neurons and pancreatic alpha cells. Neuron. 1988 Sep;1(7):605-13.

173 Rindi G, Efrat S, Ghatei MA, Bloom SR, Solcia E, Polak JM. Glucagonomas of transgenic mice express a wide range of general neuroendocrine markers and bioactive peptides. Virchows Arch A Pathol Anat Histopathol. 1991;419(2):115-29.

174 Lee YC, Asa SL, Drucker DJ. Glucagon gene 5 -flanking sequences direct expression of simian virus 40 large $\mathrm{T}$ antigen to the intestine, producing carcinoma of the large bowel in transgenic mice. J Biol Chem. 1992 May 25;267(15):10705-8.

175 Asa SL, Lee YC, Drucker DJ. Development of colonic and pancreatic endocrine tumours in mice expressing a glucagon-SV40 T antigen transgene. Virchows Arch. 1996 Mar;427(6):595-606.

176 Murphy D, Bishop A, Rindi G, Murphy MN, Stamp GW, Hanson J, et al. Mice transgenic for a vasopressin-SV40 hybrid oncogene develop tumors of the endocrine pan- creas and the anterior pituitary. A possible model for human multiple endocrine neoplasia type 1. Am J Pathol. 1987 Dec;129(3): 552-66.

177 Montag AG, Oka T, Baek KH, Choi CS, Jay G, Agarwal K. Tumors in hepatobiliary tract and pancreatic islet tissues of transgenic mice harboring gastrin simian virus 40 large tumor antigen fusion gene. Proc Natl Acad Sci U S A. 1993 Jul 15;90(14):6696-700.

178 Theuring F, Götz W, Balling R, Korf HW, Schulze F, Herken R, et al. Tumorigenesis and eye abnormalities in transgenic mice expressing MSV-SV40 large T-antigen. Oncogene. 1990 Feb;5(2):225-32.

179 Bell RH Jr, Memoli VA, Longnecker DS. Hyperplasia and tumors of the islets of Langerhans in mice bearing an elastase I-SV40 T-antigen fusion gene. Carcinogenesis. 1990 Aug;11(8):1393-8.

180 Dyer KR, Messing A. Peripheral neuropathy associated with functional islet cell adenomas in SV40 transgenic mice. J Neuropathol Exp Neurol. 1989 Jul;48(4):399-412.

181 Cartier N, Miquerol L, Tulliez M, Lepetit N, Levrat F, Grimber G, et al. Diet-dependent carcinogenesis of pancreatic islets and liver in transgenic mice expressing oncogenes under the control of the L-type pyruvate kinase gene promoter. Oncogene. 1992 Jul; 7(7):1413-22.
182 Syder AJ, Karam SM, Mills JC, Ippolito JE, Ansari HR, Farook V, et al. A transgenic mouse model of metastatic carcinoma involving transdifferentiation of a gastric epithelial lineage progenitor to a neuroendocrine phenotype. Proc Natl Acad Sci U S A. 2004 Mar 30;101(13):4471-6.

183 Gum JR Jr, Hicks JW, Crawley SC, Yang SC, Borowsky AD, Dahl CM, et al. Mice expressing SV40 $\mathrm{T}$ antigen directed by the intestinal trefoil factor promoter develop tumors resembling human small cell carcinoma of the colon. Mol Cancer Res. 2004 Sep; 2(9):504-13.

184 Ihler F, Vetter EV, Pan J, Kammerer R, Debey-Pascher S, Schultze JL, et al. Expression of a neuroendocrine gene signature in gastric tumor cells from CEA 424-SV40 large T antigen-transgenic mice depends on SV40 large $\mathrm{T}$ antigen. PLoS One. 2012;7(1): e29846.

185 Vetter E, Kronast M, Tölge M, Zimmermann W. Lgr5-expressing stem cells are not the cells of origin of pyloric neuroendocrine carcinomas in mice. J Pathol. 2016 Jan; 238(1):42-51

186 Czeh M, Loddenkemper C, Shalapour S, Schon C, Robine S, Goldscheid E, et al. The immune response to sporadic colorectal cancer in a novel mouse model. Oncogene. 2010 Dec 16;29(50):6591-602. 